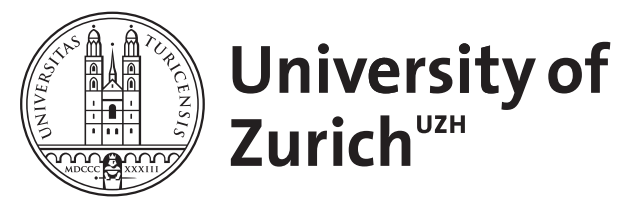

\title{
How the West "Invented" fertility restriction
}

\author{
Voigtländer, Nico ; Voth, Hans-Joachim
}

\begin{abstract}
We analyze the emergence of the first socioeconomic institution in history limiting fertility: west of a line from St. Petersburg to Trieste, the European Marriage Pattern (EMP) reduced childbirths by approximately one-third between the fourteenth and eighteenth century. To explain the rise of EMP we build a two-sector model of agricultural production - grain and livestock. Women have a comparative advantage in animal husbandry. After the Black Death in 1348-1350, land abundance triggered a shift toward the pastoral sector. This improved female employment prospects, leading to later marriages. Using detailed data from England, we provide strong evidence for our mechanism.
\end{abstract}

DOI: https://doi.org/10.1257/aer.103.6.2227

Posted at the Zurich Open Repository and Archive, University of Zurich ZORA URL: https://doi.org/10.5167/uzh-95348

Journal Article

Published Version

Originally published at:

Voigtländer, Nico; Voth, Hans-Joachim (2013). How the West "Invented" fertility restriction. American Economic Review, 103(6):2227-2264.

DOI: https://doi.org/10.1257/aer.103.6.2227 


\title{
How the West "Invented" Fertility Restriction
}

\author{
By Nico VoigtländeR AND Hans-JoAchim Voth*
}

\begin{abstract}
We analyze the emergence of the first socioeconomic institution in history limiting fertility: west of a line from St. Petersburg to Trieste, the European Marriage Pattern (EMP) reduced childbirths by approximately one-third between the fourteenth and eighteenth century. To explain the rise of EMP we build a two-sector model of agricultural production-grain and livestock. Women have a comparative advantage in animal husbandry. After the Black Death in 1348-1350, land abundance triggered a shift toward the pastoral sector. This improved female employment prospects, leading to later marriages. Using detailed data from England, we provide strong evidence for our mechanism. (JEL J12, J13, J16, N33, N53, Q11)
\end{abstract}

Technology advanced for millennia before economic growth became rapid and per capita incomes increased significantly. Fertility control allowed a transition from "Malthus to Solow" to occur. In many models of long-run growth, the demographic transition is a necessary ingredient for self-sustaining growth. It allows productivity increases to translate into higher incomes instead of a larger population (Jones 2001; Galor and Weil 2000). Historically, European incomes per capita only began to grow once fertility had fallen significantly. The same is true in the twentieth century: No developing country (except for oil producers) has attained medium income levels without going through a fertility transition beforehand (Chesnais 1992; Chenery, Syrquin, and Elkington 1975).

In contrast to the rest of the world, Europeans began to limit their fertility long before the onset of modern growth. As early as the fourteenth century, a "European Marriage Pattern" (Hajnal 1965) had emerged which combined late marriage for women with a significant share of women never marrying. West of a line from St. Petersburg to Trieste, where the European Marriage Pattern (EMP) was prevalent, Europeans avoided 25-40 percent of all possible births. The average female

\footnotetext{
* Voigtländer: UCLA Anderson School of Management, 110 Westwood Plaza, Los Angeles, CA 90095 (e-mail: nico.v@anderson.ucla.edu); Voth: Department of Economics, Universitat Pompeu Fabra, c/Ramon Trias Fargas 25-27, E-08005 Barcelona, Spain (e-mail: jvoth@crei.cat). We would like to thank four anonymous referees, as well as Stefania Albanesi, Quamrul Ashraf, Francesco Caselli, Matteo Cervellati, Hal Cole, David de la Croix, Matthias Doepke, Ruben Durante, Raquel Fernández, Alessandra Fogli, Jesus Fernandez-Villaverde, Oded Galor, Jeremy Greenwood, Avner Greif, Nezih Guner, Sebnem Kalemli-Ozcan, Dirk Krueger, Naomi Lamoreaux, Oksana Leukhina, Kiminori Matsuyama, Joel Mokyr, Nathan Nunn, Víctor Ríos-Rull, David Stromberg, Michèle Tertilt, Jaume Ventura, Dietrich Vollrath, David Weil, and Fabrizio Zilibotti for helpful comments and suggestions. Seminar audiences at EEA-ESEM, NYU, Sciences Po, Stanford SITE, UCLA, UC Louvain, UPF, University of Houston, University of Penn, University of Washington, and Warwick offered helpful advice. This paper is produced as part of the project Historical Patterns of Development and Underdevelopment: Origins and Persistence of the Great Divergence (HI-POD), a Collaborative Project funded by the European Commission's Seventh Research Framework Programme, Contract number 225342.

${ }^{\dagger}$ Go to http://dx.doi.org/10.1257/aer.103.6.2227 to visit the article page for additional materials and author disclosure statement(s).
} 
age at first marriage was 25 and 26.4 in England and Germany, respectively, in the seventeenth century. ${ }^{1}$

How did such a unique, early, and strong form of fertility limitation arise? The demographic history literature has focused on documenting EMP's key featuresthe age at first marriage, the percentage not marrying — and the areas where it came to dominate (Hajnal 1965). ${ }^{2}$ Much less attention has been paid to the reasons why Europeans "invented" fertility limitation. Earlier contributions have emphasized the importance of "girl power" (the ability of women to work outside the household and to decide whom to marry). This originated in the Catholic doctrine of mutual consent that evolved from the ninth century onward (De Moor and van Zanden 2010). ${ }^{3}$ However, despite earlier antecedents (Hallam 1985), there is a consensus that EMP only became fully developed after the Black Death in 1348-1350 (Herlihy 1997; Hajnal 1965). Christian religious doctrine is therefore necessary but not sufficient to explain the timing and scale of the rise of EMP.

In this paper, we argue that the Black Death contributed crucially to the rise of fertility limitation in Europe. By killing between a third and half of the European population, it raised land-labor ratios. Land abundance favored the land-intensive sector-animal husbandry. Because plow agriculture requires physical strength, women have a comparative advantage in livestock farming (Alesina, Giuliano, and Nunn 2011). Hence, after the Black Death, female employment opportunities improved. Working in husbandry mainly took the form of farm service-a contract that required year-round labor services in exchange for money, room, and board. As a condition of employment, all servants had to remain celibate-pregnancy and marriage resulted in termination of employment. Because many more women began to work in the booming pastoral sector after 1350, marriage ages increased. This lowered fertility in the aggregate. In a Malthusian world, there were second-round effects: lower fertility reduced population pressure, ensuring that per capita output never returned to pre-plague levels.

We build a simple Malthusian two-sector model with endogenous marriage decisions to explain the emergence of EMP. Land is in fixed supply; as population increases, incomes decline. There are two types of agricultural output, "horn" (pastoral) and "grain" (arable). Both are produced with Cobb-Douglas technology using land and labor. The only difference are the factor shares, with land having a higher weight in pastoral production. All the land in our model is owned by the lord, and is either rented out to farmers (for grain production) or operated directly (for livestock farming). Women make all important decisions. They trade off income (from wages in the horn sector) against having children (while working on the family farm in grain production). Before the Black Death, land-labor ratios are low; land is relatively dear and labor is cheap. Grain dominates the diet. Women marry early and work alongside men in family-operated arable agriculture. By killing one-third

\footnotetext{
${ }^{1}$ Similarly late marriages have only been registered again from the 1990s onward, when the respective figures were 25.1 and 26.5 (UK-ONS 2011; Flinn 1981).

${ }^{2}$ For example, EMP was more common in cultures where newly married couples set up their own households ("neolocality"). This is in contrast to the tendency of newlyweds elsewhere to live with the parents of the groom (Hajnal 1982).

${ }^{3}$ De Moor and van Zanden (2010) also emphasize limited parental authority, neolocality, and the importance of urban labor markets. We discuss related literature in more detail below.
} 
of the population, the Black Death raises land-labor ratios and thus wages. Land abundance favors the land-intensive livestock sector. In addition, consumption shifts from grain toward "luxury" goods like meat, dairy, and wool. As a result, pastoral production expands, raising female employment opportunities outside the peasant household. Marriages are postponed and childbearing is curtailed. Low fertility in turn keeps land-labor ratios relatively high, stabilizing incomes.

The empirical section systematically confronts the model's predictions with data, using fourteenth to nineteenth century England as a case study. Our theoretical setup implies that where women were employed in large numbers in agriculture, milking cows and tending sheep, marriage should occur late; and where arable agriculture dominated, marriage ages should be lower. Panel data on age at first marriage in early modern England (based on family reconstitutions from the Cambridge Group of Population Studies) confirm these predictions. An IV-strategy allows us to sidestep issues of causality, using data on weather conditions by county. We also analyze poll tax records from 1377 and 1381, documenting that these patterns were already visible shortly after the plague. In addition, as pastoral farming spread after the Black Death, many villages in England were abandoned. We use this indicator to show that in areas where cultivation switched from grain to pasture, women on average married later. Finally, we demonstrate that pastoral marriage patterns are a reliable predictor of late marriage. Overall, we estimate that without pastoral production, marriages in early modern England would have occurred more than four years earlier.

Our model has implications for the "First Divergence"-Europe's precocious rise to riches in the centuries before technological change became rapid. European per capita incomes increased to levels far above subsistence (and ahead of other regions of the world) long before the Industrial Revolution. In addition, North-Western Europe grew much faster than Southern and Eastern Europe (Maddison 1995; Acemoglu, Johnson, and Robinson 2005). While several other factors - high European death rates, the rise of Atlantic trade, and accelerating technological progress-probably played a role (Voigtländer and Voth 2013; Acemoglu, Johnson, and Robinson 2005; Mokyr 1990), fertility limitation was arguably one powerful contributor to greater riches in a Malthusian setting (Wrigley 1988; Ashraf and Galor 2011). Figure 1 illustrates how income and fertility interact in a Malthusian economy. Death rates decline in per capita income. Fertility depends on the demographic regime. Without EMP (rest of the world-ROW), fertility is constant and high. ${ }^{4}$ In Europe, it is lower on average and responds to economic conditions. The latter implies an economic "shock absorber" mechanism: hard times spell late marriages and thus low fertility, which helps to stabilize incomes. The intersection of birth and death schedules defines the steady state(s), where population and income are constant. In the absence of fertility restriction, the economy is in a low-income steady state $\left(S^{R O W}\right)$. EMP helped Europe to transition to a more benign steady state $\left(S^{\text {Europe }}\right)$, combining high incomes with low fertility. ${ }^{5}$ Areas with traditional fertility regimes (such as China) have only one steady state, combining high fertility and low per capita incomes.

\footnotetext{
${ }^{4}$ This reflects a wide consensus among demographers_-going back to Malthus' (1798) observation that outside of Europe, fertility did not respond to economic conditions, so that the "positive check" (of rising death rates) governed population dynamics.

${ }^{5}$ Other factors, in particular increasing death rates due to epidemics and warfare, had a similar effect as low birth rates (Voigtländer and Voth 2013). This reinforced the transition to a high-income Malthusian steady state.
} 


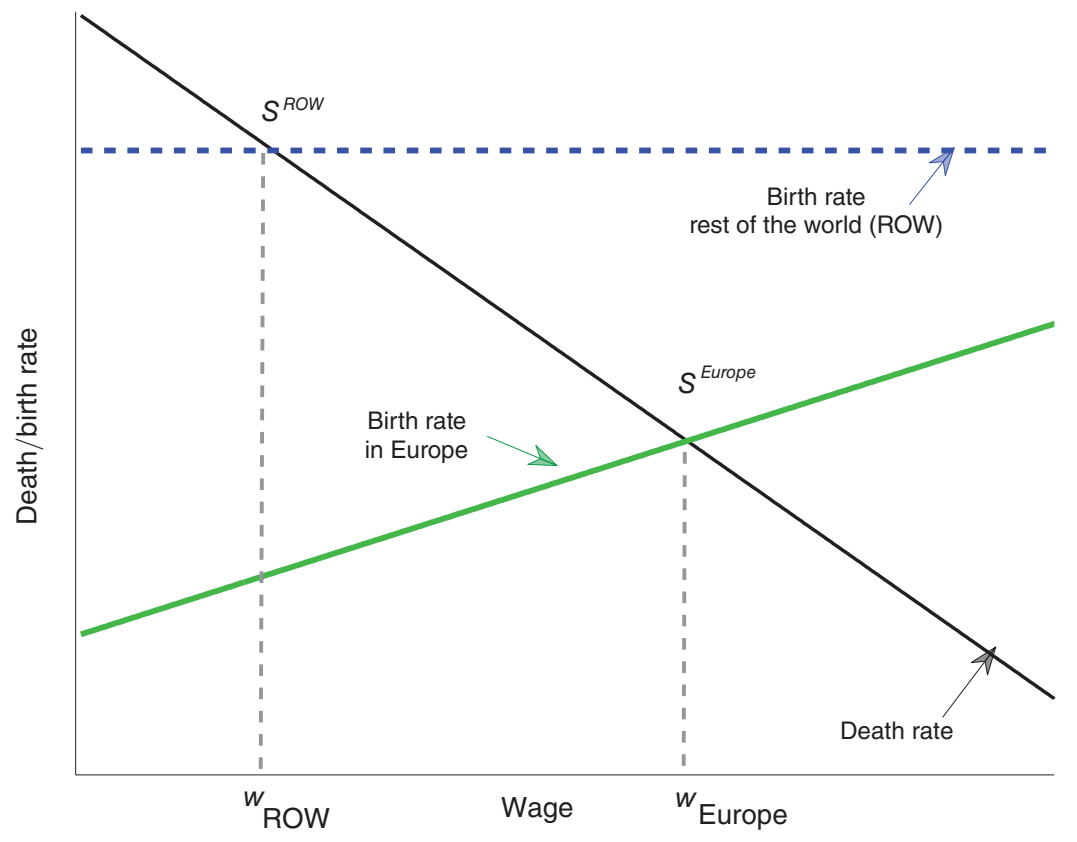

Figure 1. STEAdy States With AND Without EMP (Europe versus rest of the world)

A natural implication of our model is that land and labor productivity differences are key for explaining where fertility limitation will emerge. In areas where grain sector productivity is high, EMP will not develop. We discuss this for the case of China, where grain (rice) productivity was about four times higher than in Europe. Similarly, in Eastern Europe, where grain production was highly efficient and the Black Death had a limited impact, EMP did not emerge.

Related work on the origins of EMP includes Devolder (1999), who emphasizes the introduction of short-term leaseholds as a factor behind the rise of EMP. Foreman-Peck (2009) builds a model in which European fertility restriction follows from changes in mortality patterns. De Moor and van Zanden (2010) emphasize the role of Christianity because it requires an act of the will for marriage to be valid. They also argue that neolocality - the formation of a new household set up away from the parental home - and the rise of a landless proletariat, combined with access to urban labor markets, encouraged women to "take time to choose" their marriage partners. Finally, Mitterauer (2003) argues that feudal land holding patterns were crucial for the emergence of EMP, favoring inheritance systems that went hand in hand with the formation of nuclear households.

Our paper forms part of a broader body of work on the causes of fertility change. Demographers have typically emphasized the fall in mortality (Chesnais 1992). While intuitive, there is scant empirical support that lower child mortality reduced fertility (Galor 2005). Rising incomes are a leading alternative interpretation (Becker 1981). At the same time, as the Princeton European Fertility Project (Coale and Watkins 1986) demonstrated, the diffusion of fertility limitation in the nineteenth century is 
poorly predicted by economic factors. ${ }^{6}$ There is also work on cultural change as a main drive of fertility restriction (Coale and Watkins 1986), as well as the old-age security hypothesis (Neher 1971; Boldrin and Jones 2002). One important approach emphasizes rising returns to investments in child quality (Becker and Lewis 1973; Galor and Weil 1999). ${ }^{7}$ An alternative strand in the literature emphasizes changes in female wages (Becker 1960; Mincer 1963; Schultz 1985). Butz and Ward (1979) as well as Heckman and Walker (1990) find evidence that higher male wages raise fertility, while higher female wages lower them (Galor and Weil 1996). ${ }^{8}$

Relative to this literature, we make several contributions. We present the first rigorous model explaining the rise of EMP as a result of utility-maximizing behavior, following a large positive shock to income. In our theory, fertility restriction arises without a role for human capital, in contrast to models in the spirit of Becker and Lewis (1973). Our approach emphasizes women's opportunity cost, as determined by changes in the structure of agricultural production following the Black Death. In effect, we argue that a new socioeconomic institution emerges in response to a sharp change in factor prices. We also provide empirical support for each step of the proposed mechanism, using detailed county-level data for England during the late medieval and early modern period. Finally, we assess the overall contribution of pastoralism to delayed marriage quantitatively.

Several papers in the unified growth tradition relate to our work. In Galor and Weil (1996) female labor is more complementary to capital than male labor; capital accumulation raises female wages and lowers fertility. In our model, land plays a similar role. Because women have a comparative advantage in the land-intensive horn sector, their wages rise with the abundance of land, and fertility falls. Vollrath (2011) also builds a two-sector model in which lower labor intensity can lead to greater riches in the long run. ${ }^{9}$ Unified Growth Theory seeks a single explanation of the transition from "Malthusian stagnation" to self-sustaining, rapid growth (Galor 2005; Hansen and Prescott 2002; Galor and Moav 2002). Papers in this literature typically assume that as growth takes off, the return to human capital rises, which then lowers fertility (Lucas 2002; Galor and Weil 2000). ${ }^{10}$ The unit of analysis is the world as a whole. Instead, we focus on cross-sectional differences, examining factors that led to Europe's precocious rise to riches. We emphasize the potential for fertility to change substantially prior to the "take-off," and without changes in the return to human capital. Finally, two other features distinguish our model from existing ones. First, for very low land-labor ratios, the horn technology is not

\footnotetext{
${ }^{6}$ Recent work using disaggregated data for Bavaria and for France has questioned this conclusion (Brown and Guinnane 2001).

${ }^{7}$ Attention has also focused on the changing cost of children as a result of nineteenth-century compulsory schooling laws and factory acts restricting child labor, which also changed the cost of investment in child quality (Doepke 2004; Doepke and Zilibotti 2008).

${ }^{8}$ Doepke, Hazan, and Maoz (2012) examine changes in relative wages for women after World War II and argue that one-off negative shocks to the value of female labor increases in fertility. On the same issue, Greenwood, Seshadri, and Vandenbroucke (2005) argue that technological advances in the household sector lowered the cost of children and contributed to the baby boom.

${ }^{9}$ Vollrath (2011) shows that high labor intensity in agriculture can lead to higher fertility and therefore lower per capita income. This is compatible with our argument, where pastoral agriculture (with low labor intensity) was central for Europe's fertility restriction.

${ }^{10}$ Fernández-Villaverde (2001) presents a model in which the declining relative price of capital during the Industrial Revolution raises skill premia, and thus generates incentives to trade child quality for quantity.
} 
economically viable because women's wages in horn are below their counterpart in grain production. Thus, the mechanism leading to fertility decline does not operate in a land-scarce economy. Second, married couples cannot control their fertility. Instead, the number of children results from a trade-off between female work time away from home and married life with home production. This reflects the historical fact that effective contraception was unavailable in early modern times; delayed marriage (and fewer women marrying) was the only way to reduce fertility.

We are not the first to argue that the Black Death caused important changes in the European economy. Van Zanden (2002) concluded that the rapid rise of the Netherlands during the early modern period owed much to the economy's transformation after 1350. Epstein (2000) argued that institutional constraints on growth were removed by the plague. Herlihy (1997) speculated that the emergence of fertility restriction may have been linked to the effects of population losses after the plague, and Smith (1981) suggested that the rise of farm service may have been one of the reasons for greater fertility control. Finally, Pamuk (2007) surveys the evidence that the Black Death ushered in a transformation of the European economy, reducing and then reversing the income gap between Southern and Northwestern Europe. ${ }^{11}$

We proceed as follows: Section I discusses the historical background. In Section II we present our model and focus on several international comparisons. Section III presents our empirical analysis. Section IV concludes.

\section{Historical Background}

In this section, we summarize the existing state of historical knowledge about the rise and fall of fertility restriction in early modern Europe.

Two main factors curtailed fertility under EMP_late female marriage and a high percentage of women never marrying. In the Roman Empire, age at first marriage was 12-15 for pagan girls, and somewhat higher for Christian girls. Herlihy (1985) estimates that by $500 \mathrm{AD}$, the average marriage age for women in Western Europe was 18-19 years. During the Middle Ages, this number may have been slightly higher than in Roman times. For a group of medieval Lincolnshire villages, Hallam (1985) estimated ages at first marriage for women of around 20. ${ }^{12}$ Among the English nobility, marriage at age 17 was common in the twelfth century. Numbers for fourteenth-century Tuscany are similar (Herlihy 1985). Central features of EMP-a marriage age above the biological age of fertility, and some women never marrying-probably originated in some areas before the fourteenth century (Laslett and Wall 1972). However, the European Marriage Pattern, with the age at first marriage postponed to 25 or beyond, only emerged after the Black Death, and the pattern was

\footnotetext{
${ }^{11}$ The nature of the Malthusian world before 1800 is examined inter alia in Wrigley et al. (1997), Kremer (1993), Clark (2007), and Ashraf and Galor (2011). The extent to which negative shocks raised death rates and lowered fertility rates is discussed by Lee and Anderson (2002); Galloway (1988); Crafts and Mills (2009); and Kelly and Ó Grada (2008).

${ }^{12}$ The percentage of females never married needs to be established through family reconstitutions, which track cohorts over the entire life cycle. For the period before 1500, these are not available. Instead, one can look at the proportion of women unmarried at a particular point in time. Because some women will eventually find husbands and have children, this constitutes a strict upper bound on the percentage never marrying. In St. Germain-des-Prés in 801-820, for example, some 16 percent of adults were unmarried. The proportion of unmarried women was probably much less. In the ninth century, in Villeneuve-Saint-Georges, up to 12 percent of adults had never married (Hallam 1985).
} 
Table 1-Age of Marriage and Marital Fertility in Seventeenth-Century Europe

\begin{tabular}{lcc}
\hline \hline & $\begin{array}{c}\text { Average age of women } \\
\text { at first marriage }\end{array}$ & $\begin{array}{c}\text { Cumulative marital } \\
\text { fertility (20-44) }\end{array}$ \\
\hline England & 25 & 7.6 \\
France & 24.6 & 9 \\
Belgium & 25 & 8.9 \\
Germany & 26.4 & 8.1 \\
Scandinavia & 26.7 & 8.3 \\
Switzerland & - & 9.3 \\
\hline
\end{tabular}

Note: Cumulative marital fertility $=$ number of live births per married women aged 20-44.

Source: Flinn (1981)

strongest in Northwestern Europe (Hajnal 1965, 1982). For English women, the age at first marriage in the early modern period was 25 years; 17.5 percent never married. Scandinavians married even later. Table 1 gives an overview.

Within marriage, fertility was largely unconstrained. To show this, Clark (2007) compares Western European marital fertility with contemporaneous levels of Hutterites (a modern-day Canadian sect that rejects birth control). He finds that both are very similar, implying that fertility within marriage in early modern Europe was probably close to the biological maximum (see online Appendix D for more detail).

Northwestern Europe in particular evolved a "low pressure demographic regime" (Wrigley et al. 1997, p. 247). Negative economic shocks were largely absorbed through Malthus's preventive check (lower nuptiality), rather than the positive check (death rates surging). As economic conditions worsened, fertility declined. As life expectancy fell and conditions became less favorable, partly under the influence of declining land-labor ratios in England after 1600, the age at marriage increased, and gross reproduction rates fell (Wrigley and Schofield 1981; Wrigley et al. 1997). This helped to reduce the downward pressure on living standards.

Late marriage was arguably voluntary: children were often independent from their parents by their teenage years, and became fully legally independent at age 21 - several years before the average age at first marriage. The law did not ban early marriages. In England, the legal age for marriage was 12 for women and 14 for men (Clark 2007). While the authorities hoped to raise age at marriage - through apprenticeships, for example - there were many ways to ignore or circumvent restrictions, especially in the larger towns (Ingram 1985; Clark 2007). Nor is there evidence that the "passion between the sexes" (as Malthus 1798, p. 12 called it) was any less acute in early modern Europe than elsewhere. One out of seven marriages in seventeenth century England was followed by the bride giving birth within eight months; the proportion could be as high as 40 percent (Wrigley and Schofield 1981).

Apprenticeships and service in agriculture played an important role in postponing marriage. A significant part of young men and women were thus employed, especially in Northwestern Europe; in England, up to half of all boys and girls aged 15-25 worked as servants (Kussmaul 1981). ${ }^{13}$ After 1349, landlords increasingly hired agricultural servants to work on the larger farms (Kussmaul 1981). The

\footnotetext{
${ }^{13}$ For example, Hajnal (1982) gives the share of women aged 20-24 working as servants in the early modern period as 51 percent in Denmark, 44 in Iceland, 36 in Holland, 40 in England, and 33 (both sexes) in Norway.
} 
Museum Rusticum (1765), an eighteenth century periodical on rural affairs, called service "a covenanted state of celibacy." Marriage typically implied an immediate termination of service. Kussmaul (1981) calculates that 65 percent of servants married immediately before or after the end of their contracts. Celibacy was both a convention and a technological requirement. Pastoralism has fairly steady labor requirements throughout the year. This makes it attractive to employ servants yearround, instead of hiring agricultural laborers on daily wages. Marriage and childbearing reduces female labor supply, and makes it more variable. As such, it would have been incompatible with the labor requirements in pastoral agriculture. As the English philosopher David Hume put it in 1742: "All masters ... admit not by any means the marrying of the female, who are then supposed altogether incapacitated for their service" (Hume 1854, p. 430). Servants were entitled to room and board in exchange for labor services. Housing married maids and their offspring would have involved a heavy additional expense. The system also had advantages for the servants. As Macfarlane (1970) observed, "the system of farming out the children, which permitted them a moderate freedom without forcing them to resort to marriage, allowed them to marry late."

EMP in England declined in the second half of the eighteenth century. After the 1730s, mean ages at first marriage trended down for both men and women. A number of factors reduced female employment opportunities in husbandry. As grain prices rose in the eighteenth century relative to the price of meat and dairy products, pastoral production declined (Snell 1981). In addition, economic change undermined the institution of farm service for young women. Cottage shop manufacturing offered a chance to earn a living while having children. Female earnings opportunities outside of animal husbandry improved; thus women could marry earlier, and still earn the same. By the 1830s, age at marriage had fallen from 26 for women (and 27 for men) in 1700 to 23 (and 25, respectively). Population growth accelerated from zero to 1.75 percent per annum (Wrigley et al. 1997). Using Kussmaul's (1990) marriage seasonality measure as a proxy for farm service, Schellekens (1997, 2001) shows that the decline of service in husbandry is a major explanation for the rise in nuptiality. The decline of England's low fertility regime was thus brought on by the same factors that led to its rise during the early modern period-changes in the opportunity cost of female labor, as determined by demand conditions in husbandry.

\section{Model}

This section presents a simple Malthusian model with endogenous labor supply and marriage decisions. The economy is composed of a mass of $N$ female and $N$ male peasants who work, consume, and procreate. ${ }^{14}$ People live for two periods, childhood and adulthood. Children do not work or consume. For simplicity, we assume that adulthood and childhood are of equal length and that wages are the only source of income for peasants. There are two agricultural sectors of production, grain, and

\footnotetext{
${ }^{14}$ We call all economic agents that are not large landowners "peasants" (landholders subsisting by working a small plot). Note that in England, there were no peasants in the strict sense of the word. Instead, most tenant farms were relatively large (as we discuss in Section I), and were often operated with hired labor. We use the "peasant" terminology for simplicity. In our model, it merely implies that large landowners have an advantage producing pastoral products compared to "peasants."
} 
horn (e.g., meat, milk, and wool). All men are equal; they rent land on which they operate small grain farms. Women differ with respect to physical strength, and thus in terms of their productivity in the strenuous grain sector. ${ }^{15}$ Physical strength matters less for pastoral production, so that all women are equally suited for the horn sector. Only unmarried women can work in horn.

When they become adults, women decide when to marry, maximizing their expected utility. Before marriage, they do not have children. During marriage, there is no birth control and children arrive with frequency $\pi$. Delaying marriage is thus the only "contraceptive technology." Women can earn a wage premium in pastoral production as long as they are unmarried. This implies a trade-off between income and marriage, which endogenously determines the age at marriage and thus fertility. We define the European Marriage Pattern as follows:

DEFINITION 1: Let $\bar{b}$ be the birth rate when women spend all their adult life married. Then EMP is a demographic regime that involves $(i) b<\bar{b}$ because women remain unmarried throughout a part of adulthood, and (ii) b increases in per capita income.

The economy is Malthusian - a steady state is determined by the intersection of the mortality and fertility schedules. The former declines in consumption, while the latter depends on the demographic regime. In the absence of EMP, the fertility schedule is flat, as shown in Figure 1. Without EMP, the economy is in a steady state with high, constant birth rates and low per capita income ( $S^{R O W}$ in Figure 1). With EMP, the birth schedule shifts downward due to delayed marriage (property (i) of EMP). In addition, an income effect causes birth rates to increase with wages (property (ii)). The new steady state has lower birth rates, combined with higher per capita incomes. We argue that the Black Death contributed to the transition from a low- to a high-income steady state in Western Europe after the Black Death. Our mechanism can explain the slow rise of population levels after 1349, and the persistence of higher output per capita in Europe. We also discuss productivity characteristics that favor the emergence of EMP in Europe as compared to China.

In the following, we describe the central components of the model. We first build the intuition for the mechanism by focusing on the labor supply side, and then derive the Malthusian equilibria, accounting for the fact that livestock products were "luxury goods."

\section{A. Peasant Families: Preferences, Labor Supply, and Fertility}

Adult peasants live for one period. All men are equal, while women differ in their physical strength. Female strength relative to men $\rho \in(0,1)$ is randomly distributed, as given by the probability density function $f(\cdot)$. Hereafter, we use the subscript $i$ to refer to a particular strength draw, $\rho_{i}$, and thus to the different "types" of

\footnotetext{
${ }^{15}$ In our model, female strength differences have very similar effects to other forms of heterogeneity (such as TFP differences in arable farming, or region-specific advantages in pastoral land suitability). While heterogeneity in female strength is not crucial for our main result - the emergence of EMP - it adds historical realism and ensures that aggregate fertility is a smooth function of per capita incomes.
} 
women. Because EMP is closely associated with women deciding when to marry (De Moor and van Zanden 2010), we focus on the female optimization problem. In the spirit of Galor and Weil (1996), women draw utility from consumption and children:

$$
u\left(C_{i}, b_{i}\right)=(1-\mu) v\left(C_{i}\right)+\mu \ln \left(b_{i}-\underline{b}\right),
$$

where $v\left(C_{i}\right)$ denotes utility from a consumption composite throughout adult life, $b_{i}$ is the number of children (with a lower bound $\underline{b}$ ), and $\mu$ represents the relative importance of children versus consumption in women's utility. There are no investments or bequests to children-all income is spent on consumption during adult life. We assume that male strength is homogeneous, and that men's consumption preferences are identical to those of women. When women decide to marry, they all receive the same (random) match as a husband. All relevant decisions in the model are thus made by women. Consumption utility throughout the adult period is given by ${ }^{16}$

$$
v\left(C_{i}\right)=\left\{\begin{array}{ll}
\ln \left(C_{i}-\underline{c}+\epsilon\right) & \text { if } C_{i}>\underline{c} \\
\left(C_{i}-\underline{c}\right) / \epsilon+\ln (\epsilon) & \text { if } C_{i} \leq \underline{c}
\end{array},\right.
$$

where $\epsilon$ is a positive number close to zero. This specification ensures that $v$ and $v^{\prime}$ are continuous and that the marginal utility is a large positive number whenever $C_{i} \leq \underline{c} .{ }^{17}$ Whether or not income is above the reference level $\underline{c}$ plays a central role in our model. We think of $\underline{c}$ as the per capita consumption that fulfills basic needs, but does not yet include any luxury items (such as meat products). Below $\underline{c}$, the marginal utility of consumption is high, and it falls rapidly as consumption exceeds $\underline{c} .{ }^{18}$ This setup delivers an income effect: Fertility rises when consumption grows beyond $\underline{c} .{ }^{19}$ Consumption utility is drawn from two goods: Grain $\left(c_{i, g}\right)$ and horn products $\left(c_{i, h}\right)$. We use grain as the numeraire; the price of horn goods is denoted by $p_{h}$. To focus on the main mechanism, we take $p_{h}$ as given, only assuming that horn is not an inferior good so that $p_{h}$ is non-decreasing in income. In Section IIF we introduce non-homothetic preferences where the expenditure share for horn products rises with income above the reference level $\underline{c}$.

Male and female peasants each provide one unit of labor during adulthood. Men earn the uniform male wage rate in grain production, $w_{M g}$. Women split their labor supply between the horn and the grain sector. In line with the historical evidence

\footnotetext{
${ }^{16}$ Consumption utility is derived from total income throughout adult life. This implicitly assumes that (i) women do not discount within the adult period and (ii) consumption at different points throughout adult life is perfectly substitutable. One could split the adult period into an unmarried and a married part with different consumption levels. This would add realism (and complexity), but not change our qualitative results.

${ }^{17}$ We use $\underline{c}=1$, so that $\lim _{C_{i} \rightarrow \underline{c}} v\left(C_{i}\right)=\ln (\epsilon)$ and $\lim _{C_{i} \rightarrow c} v^{\prime}\left(C_{i}\right)=1 / \epsilon$ for convergence to $\underline{c}$ from above and below.

${ }^{18}$ The reference level $\underline{c}$ is thus similar to subsistence consumption, with one important difference: People do not starve below this level; they merely value consumption more because their basic material needs are unmet. This allows us to include the consumption range below $\underline{c}$ as an integral part of the model.

${ }^{19}$ The income effect is stronger the closer $C_{i}$ is to $\underline{c}$. It is thus similar to the "subsistence effect" that Jones (2001) integrates in the standard fertility framework (Barro and Becker 1989). For very high income levels $\left(C_{i}>>\underline{c}\right)$, our preferences behave as in the standard log-case (c.f. Galor and Weil 1996)_further increases in income have no effect on birth rates.
} 
on animal husbandry (Section I), marriage is not allowed for women working as servants in the horn sector. Women spend a share $l_{i, h}$ of their adult life in horn production, being unmarried and earning $w_{h}$. The remainder $1-l_{i, h}$ is married life with work in grain production on the peasant farm. ${ }^{20} \mathrm{~A}$ woman's marginal product in peasant grain production depends on her physical strength (relative to men) and is given by $w_{i, F g}=\rho_{i} w_{M g}$, with $\rho_{i}<1$. Female income throughout the adult period is thus

$$
I_{i}=w_{h} l_{i, h}+\rho_{i} w_{M g}\left(1-l_{i, h}\right) .
$$

Female labor supply is determined by the trade-off between earnings in horn production (i.e., if $w_{h}>w_{i, F g}$ ) and child rearing during marriage. While single, the probability of childbearing is zero. After marrying, husband and wife form a new household, and women work in grain production on the peasant farm. The share of adult lifetime married thus corresponds to female labor supply in the grain sector, $l_{i, F g}=1-l_{i, h} \cdot{ }^{21}$ There is no contraception, and married couples produce $\pi$ births per unit of time. ${ }^{22}$ Consequently, the number of offspring for woman $i$ is given by

$$
b_{i}=\pi\left(1-l_{i, h}\right)
$$

Given $\rho_{i}, w_{M g}$, and $w_{h}$, women maximize (1) subject to the consumption utility given by (2), their income (3), and the birth rate given by (4). In the absence of bequests and investments, the budget constraint holds with equality, i.e., $C_{i}=I_{i}{ }^{23}$ The female optimization problem is then

$$
\begin{gathered}
\max _{l_{i, h}}\left\{(1-\mu) v\left(I_{i}\left(l_{i, h}\right)\right)+\mu \ln \left[\pi\left(1-l_{i, h}\right)-\underline{b}\right]\right\} \\
\text { s.t. } 0 \leq l_{i, h} \leq 1 .
\end{gathered}
$$

When $w_{h} \leq w_{i, F g}$ (i.e., labor in horn is not attractive for women of strength $\rho_{i}$ ), this simplifies to the corner solution $l_{i, h}=0$. The interior solution to the female optimization problem is described in more detail below.

Finally, we describe mortality in our model. Death rates among adults are zero until a given period is over. Overall mortality is thus driven exclusively by child mortality. ${ }^{24}$ The survival of children depends on average consumption. The death rate is given by

$$
d=d_{0}\left(\bar{c}^{p} / \underline{c}\right)^{\varphi_{d}}
$$

\footnotetext{
${ }^{20}$ Because only women work in horn production, we do not need extra subscripts for male or female peasants; the subscript $h$ is sufficient. Historically, men also worked in pastoral farming. Here we make the simplifying assumption that they only work in grain production on their rented farm land. What is important for our mechanism is that women work relatively more in horn.

${ }^{21}$ We implicitly assume that working in grain production is compatible with raising children.

${ }^{22}$ For simplicity, we treat $\pi$ as a deterministic frequency, rather than as probability draws. In addition, we assume that child mortality does not directly influence birth rates. Thus, there is no role for precautionary children in our model.

${ }^{23}$ For now, we use this simplified notation. In Section IIF we introduce an appropriately defined aggregator function $C_{i}$ of the two types of consumption goods.

${ }^{24}$ Historically, child mortality was the main driver of overall life expectancy.
} 
where $\varphi_{d}<0$ is the elasticity of child mortality with respect to average per capita consumption of peasants $\left(\bar{c}^{p}\right)$, and $d_{0}$ is the death rate at the reference consumption level $\underline{c} .{ }^{25}$ Consequently, mortality falls as per capita income rises. Despite the fact that individuals cannot satisfy all their material needs below $\underline{c}$, there is no spike in mortality - the death rate increases continuously as $\bar{c}^{p}$ falls below $\underline{c}$. At the end of each period, parents die and surviving offspring form the next adult generation.

The optimization problem is static, which simplifies our analysis. This is similar to Jones (2001) and can be derived from a more general dynamic optimization problem under two assumptions that we make. First, utility depends on the flow of births rather than on the stock of children. That is, parents care about their own children, but not about their children's offspring. Second, we assume in (6) that child mortality depends on average per capita consumption. Since women take average consumption as given, child mortality does not interfere with their optimal labor supply decision. With these assumptions, the more general dynamic optimization problem (e.g., Barro and Becker 1989) reduces to a sequence of static problems as given in $(5)$.

\section{B. The Landlord, Location of Production, and Technology}

Both technologies — grain $(g)$ and horn $(h)$ - use land and labor as inputs. A landlord owns all land $T$, which is in fixed supply. He does not work. Peasants rent land $T_{g}$ for grain production. On the remaining land $T_{h}=T-T_{g}$, the landlord operates large-scale horn production, hiring female workers and paying them their marginal product as wages. ${ }^{26}$ We assume that the horn technology is only available to owners of large estates, i.e., to the landlord in our model. This is motivated by size differences between arable and pastoral farms (Campbell 2000). ${ }^{27}$

The landlord does not work and does not derive utility from children; he is infinitely-lived. Therefore, he does not influence fertility directly. The landlord's only source of income are land rents, generated by charging the marginal product of land in the two sectors, $r_{g}$ and $r_{h}$. He uses his income in each period to finance activities that are unrelated to agricultural production (e.g., building castles or engaging in warfare). Thus, his expenditure does not affect the relative demand for grain versus horn products. The landlord maximizes rental income, allocating land optimally between the two sectors:

$$
\max _{T_{g}}\left\{r_{g} T_{g}+r_{h}\left(T-T_{g}\right)\right\}
$$

\footnotetext{
${ }^{25}$ A historical justification for child mortality depending on average (rather than individual) income is that its main cause were diseases like diarrhea and typhus, whose spread depends on hygienic conditions (and therefore income) in the community.

${ }^{26}$ Alternatively, we could assume that landlords manage the production on all their land, paying grain and horn workers their marginal product. The crucial assumption for our mechanism is that large-scale horn production requires female workers to remain celibate.

${ }^{27}$ A minimum land requirement for horn production would have similar implications for who produces horn. To save on notation and concentrate on the main mechanism, we do not model this dimension explicitly. Instead we assume that only the landlord produces horn; peasants can only grow grain on the farm land that they rent.
} 
Horn output is produced according to

$$
Y_{h}=A_{h} L_{h}^{\alpha_{h}} T_{h}^{1-\alpha_{h}},
$$

where $A_{h}$ denotes total factor productivity (TFP), $T_{h}$ is land used for pastoral production, and $L_{h}$ is total labor input in this sector. The grain technology is more labor-, and less land-intensive than horn production. This is represented by $\alpha_{g}>\alpha_{h}$ in the production function

$$
Y_{g}=A_{g} \hat{L}_{g}^{\alpha_{g}} T_{g}^{1-\alpha_{g}},
$$

where $A_{g}$ and $\alpha_{g}$ are TFP and the labor share in grain production, respectively; $T_{g}$ is land dedicated to grain, and $\hat{L}_{g}$ denotes effective peasant grain-labor supply. The latter is given by

$$
\hat{L}_{g}=L_{M, g}+L_{F, g},
$$

where $L_{M, g}$ and $\hat{L}_{F, g}$ denote total male and effective female grain-labor input, respectively. While both types of labor are perfectly substitutable, men have a relative advantage compared to women because grain farming requires arduous physical labor, such as ploughing, threshing, and reaping. This is captured by the relative strength parameter $\rho_{i}<1$ introduced above. Because there is a mass $N$ of peasant households, grain labor supply can be expressed as $\hat{L}_{g}=N \cdot \hat{l}_{g}$. The lower case letter denotes the average effective grain labor supply by peasant households, which is equal to the sum of average male and female labor in grain:

$$
\hat{l}_{g}=l_{M, g}+\int_{0}^{1} \rho_{i} \cdot l_{i, F g}\left(\rho_{i}\right) f\left(\rho_{i}\right) d \rho_{i}=1+\int_{0}^{1} \rho_{i} \cdot\left(1-l_{i, h}\left(\rho_{i}\right)\right) f\left(\rho_{i}\right) d \rho_{i} .
$$

To derive the second equality, we used the fact that men work in grain throughout adulthood $\left(l_{M, g}=1\right)$, while women split their labor supply across the two sectors, $l_{i, F g}+l_{i, h}=1$. The integral in (11) is the average effective female labor supply in grain, across all strength types $\rho_{i}$. Note that $l_{i, h}\left(\rho_{i}\right)$ is the share of adult lifetime that a woman with strength $\rho_{i}$ spends working in horn production, so that $\rho_{i}\left(1-l_{i, h}\left(\rho_{i}\right)\right)$ is her effective labor supply in grain. Correspondingly, the average horn labor supply per woman (and thus per peasant household) is given by $l_{h}=\int_{0}^{1} l_{i, h}\left(\rho_{i}\right) f\left(\rho_{i}\right) d \rho_{i}$, while $L_{h}=N \cdot l_{h}$ is the total labor supply in horn.

Because peasants do not have access to the large-scale horn technology, production occurs as follows: Peasants grow grain on rented land, while the landlord engages in livestock farming on large demesnes. Peasant households (where the woman has strength $\left.\rho_{i}\right)$ rent land $t_{g}\left(\rho_{i}\right)$ for grain production. Thus, the average rented land per household is $t_{g}=\int_{0}^{1} t_{g}\left(\rho_{i}\right) f\left(\rho_{i}\right) d \rho_{i}$. We normalize aggregate land by the mass of peasant households: $t=T / N$ so that average pastoral land per household is $t_{h}=t-t_{g}$. This completes the basic setup of our model. Next, we derive factor payments and show how land is allocated between grain and horn production. In addition, we examine the female labor supply decision. 


\section{Factor Payments and Allocation of Labor}

When pastoral production occurs, the landlord pays a wage rate equal to the marginal product of labor in (8), taking the relative price of horn $p_{h}$ as given: ${ }^{28}$

$$
w_{h}=\alpha_{h} p_{h} A_{h}\left(\frac{T_{h}}{L_{h}}\right)^{1-\alpha_{h}}=\alpha_{h} p_{h} A_{h}\left(\frac{t_{h}}{l_{h}}\right)^{1-\alpha_{h}} \text {. }
$$

Next, we turn to arable production. When growing grain on rented land, the marginal product of male labor follows from (9) and is given by

$$
w_{M g}=\alpha_{g} A_{g}\left(\frac{T_{g}}{\hat{L}_{g}}\right)^{1-\alpha_{g}}=\alpha_{g} A_{g}\left(\frac{t_{g}}{\hat{l}_{g}}\right)^{1-\alpha_{g}} \text {. }
$$

The marginal product of a married woman in home grain production depends on her strength and is given by $w_{i, F g}=\rho_{i} w_{M g}$.

Peasant households pay the rental rate $r_{g}$, while the return to land in horn production is $r_{h}$, as given by

$$
r_{g}=\left(1-\alpha_{g}\right) A_{g}\left(\frac{\hat{l}_{g}}{t_{g}}\right)^{\alpha_{g}}, \quad r_{h}=\left(1-\alpha_{h}\right) p_{h} A_{h}\left(\frac{l_{h}}{t_{h}}\right)^{\alpha_{h}}
$$

The landlord's optimal allocation of land according to equation (7) implies $r_{g}=r_{h}=r$. This yields

$$
\frac{t_{h}}{l_{h}}=\left(\frac{p_{h} A_{h}}{A_{g}} \frac{1-\alpha_{h}}{1-\alpha_{g}}\right)^{\frac{1}{\alpha_{h}}}\left(\frac{t_{g}}{\hat{l}_{g}}\right)^{\frac{\alpha_{g}}{\alpha_{h}}} .
$$

This equation says that the land-labor ratio in horn is proportional to its efficiencyadjusted counterpart in grain production, provided that both sectors operate. Land per unit of labor in horn relative to grain increases (i) in the TFP ratios-relatively more land is dedicated to the more productive technology, (ii) in the price of horn $p_{h}$, and (iii) in the land-intensity of horn relative to grain, as governed by $\alpha_{h}$ and $\alpha_{g}$.

Much of our analysis relies on changes in the aggregate land-labor ratio $t$. With decreasing returns to labor in both sectors, larger $t$ spells higher wages. The following proposition shows how sector-specific land-labor ratios change with their aggregate counterpart. The response of $p_{h}$ to income (and thus, $t$ ) is important in this context. For now, we merely assume that $d p_{h} / d t \geq 0$ (horn is not an inferior good). In Section IIF we explicitly model demand for the two goods.

\footnotetext{
${ }^{28}$ Note that the ratio of pastoral land per household to the labor supply in horn per average peasant household, $t_{h} / l_{h}$, is equivalent to the aggregate land-labor ratio in horn, $T_{h} / L_{h}$. The same is true for the strength-adjusted landlabor ratio in grain production. In the interest of simplicity, we use the terminology "land-labor ratio" in horn and grain in the following, whenever we refer to the ratios $t_{h} / l_{h}$ or $t_{g} / \hat{l}_{g}$.
} 
PROPOSITION 1: If both technologies operate and the aggregate land-labor ratio $t=T / N$ grows, then the land-labor ratio in horn will also increase: $\frac{d\left(t_{h} / l_{h}\right)}{d t}>0$.

\section{PROOF:}

If both technologies operate and average land per household $t$ increases, factor market clearing implies that land-labor ratios must increase in at least one of the two sectors. First, suppose that $d p_{h} / d t=0$. Then, following $(15), d\left(t_{g} / \hat{l}_{g}\right) / d t$ and $d\left(t_{h} / l_{h}\right) / d t$ have the same sign. Consequently, both derivatives are strictly positive. Second, suppose that $d p_{h} / d t>0$. In this case following (15), if $d\left(t_{g} / \hat{l}_{g}\right) / d t>0$, then $d\left(t_{h} / l_{h}\right) / d t>0$. On the other hand, if $d\left(t_{g} / \hat{l}_{g}\right) / d t \leq 0$, then $d\left(t_{h} / l_{h}\right) / d t>0$ must hold because the land-labor ratio must increase in at least one of the two sectors when $t$ rises.

Next, we rearrange (15) and substitute it into (13) to derive the wage rate in grain as a function of the horn land-labor ratio:

$$
w_{M g}=\alpha_{g} A_{g}\left(\frac{A_{g}}{p_{h} A_{h}} \frac{1-\alpha_{g}}{1-\alpha_{h}}\right)^{\frac{1-\alpha_{g}}{\alpha_{g}}}\left(\frac{t_{h}}{l_{h}}\right)^{\frac{\alpha_{h}}{\alpha_{g}}\left(1-\alpha_{g}\right)} .
$$

We have now obtained all wage rates as functions of the land-labor ratio in horn, $t_{h} / l_{h}$. Finally, we derive the female wage premium in horn production. We divide (12) by the female marginal product in grain production (using (16) and $w_{M g}$ $\left.=w_{i, F g} / \rho_{i}\right)$ to obtain:

$$
\frac{w_{h}}{w_{i, F g}}=\frac{\alpha_{h}}{\rho_{i} \alpha_{g}}\left(\frac{p_{h} A_{h}}{A_{g}}\right)^{\frac{1}{\alpha_{g}}}\left(\frac{1-\alpha_{h}}{1-\alpha_{g}}\right)^{\frac{1-\alpha_{g}}{\alpha_{g}}}\left(\frac{t_{h}}{l_{h}}\right)^{\frac{\alpha_{g}-\alpha_{h}}{\alpha_{g}}} .
$$

The return to female labor in horn versus grain is therefore driven by four components in our model. First, if horn technology is highly productive relative to grain technology $\left(A_{h} / A_{g}\right.$ is large $)$, female wages in horn are comparably high. Second, the same is true if horn products are in high demand, such that $p_{h}$ is high. Third, $w_{h} / w_{i, F g}$ is low if women are relatively productive in grain ( $\rho_{i}$ is high). Finally, $w_{h} / w_{i, F g}$ grows when land becomes more abundant, as the following corollary shows.

COROLLARY 1: Provided that both sectors operate, the female wage premium in horn is increasing in the aggregate land-labor ratio: $d\left(w_{h} / w_{i, F g}\right) / d t>0, \forall i$.

\section{PROOF:}

Since $\alpha_{g}>\alpha_{h}, d p_{h} / d t \geq 0$, and $d\left(t_{h} / l_{h}\right) / d t>0$ (Proposition 1$)$, this result follows from deriving (17) with respect to $t$.

Because of Corollary 1, abundance in land after the Black Death makes the horn sector more attractive to female labor. In addition, if horn products are superior goods (as historical evidence strongly suggests), higher demand due to increased income $\left(d p_{h} / d t>0\right)$ reinforces this effect. 


\section{Fertility and Female Labor Supply for Given Strength $\rho_{i}$}

Female labor supply in horn production_-and thus fertility-depends crucially on the female wage premium in horn, which in turn rises and falls with the abundance of farmland. In the following, we explain this mechanism for a given female strength $\rho_{i}$. The optimization problem (5) yields (for illustration, we substitute $b_{i}$ and $I_{i}$ back into the solution):

$$
b_{i}-\underline{b}=\left\{\begin{array}{ll}
\pi \frac{\mu}{1-\mu} \frac{I_{i}-\underline{c}+\epsilon}{w_{h}-w_{i, F g}} & \text { if } I_{i}>\underline{c} \\
\pi \frac{\mu}{1-\mu} \frac{\epsilon}{w_{h}-w_{i, F g}} & \text { if } I_{i} \leq \underline{c}
\end{array} .\right.
$$

This solution depends crucially on whether or not there is a female wage premium in horn, $w_{h}>w_{i, F g}$. We first consider the case where $w_{h} \leq w_{i, F g}$. Then, increasing $l_{i, h}$ unambiguously lowers female welfare because both income and birth rates fall according to (3) and (4), respectively. Thus, female workers do not supply labor in horn production, and we obtain a corner solution with $l_{i, h}=0$ and $b_{i}=\pi$. This holds for both $I_{i}>\underline{c}$ and $I_{i} \leq \underline{c}$.

Next, we describe the solution when horn labor offers a wage premium, $w_{h}>w_{i, F g}$. In the following, we refer to this case as horn production being economically viable for women of strength $\rho_{i}$. If the income condition $I_{i}>\underline{c}$ holds, the first line in (18) describes the solution, and the birth rate $b_{i}$ increases in wages (income effect). At the same time, $b_{i}$ falls in the horn wage premium, because a higher $w_{h}>w_{i, F g}$ makes celibate work time more rewarding for women (wage premium effect). Which of the two effects dominates depends on how close income is to $\underline{c}$, and is discussed in detail below. Finally, for incomes below $\underline{c}$, the second line in (18) describes the solution, which depends on the ratio of $\epsilon$ to $w_{h}-w_{i, F g}$. Because $\epsilon$ is infinitesimal, any $w_{h}>w_{i, F g}$ implies that this ratio is very small. Thus, birth rates are at (or close to) the minimum: $b \simeq \underline{b}$.

Summing up, we distinguish between three regimes for birth rates. When horn does not offer a wage premium $\left(w_{h} \leq w_{i, F g}\right)$, birth rates are constant and high; in the presence of a wage premium $\left(w_{h}>w_{i, F g}\right)$ birth rates are low and constant if income is below $\underline{c}$, and increasing in income if it exceeds $\underline{c}$. Equation (19) gives the corresponding results for female labor supply in horn, $l_{i, h}$. We begin with a low landlabor ratio, such that horn is not economically viable for women of strength $\rho_{i}$ (i.e., $\left.w_{h} \leq w_{i, F g}\right)$; hence, $l_{i, h}=0$. When land-labor ratios rise and horn labor becomes attractive given strength $\rho_{i}$, the solution depends on whether or not female income $I_{i}$ exceeds $\underline{c}$. If it does not, we are in the second regime of (19), and women of type $i$ work the maximum time in horn, $l_{i, h}=\bar{l}_{h}$, which just ensures $\underline{b}$ children $\left(\bar{l}_{h} \equiv 1-\underline{b} / \pi\right)$. If income exceeds $\underline{c}$, we obtain the internal solution given by the third regime. ${ }^{29}$

\footnotetext{
${ }^{29}$ Theoretically, there is an additional corner solution that may result in the third regime: If the fraction term is larger than $(1-\mu) \bar{l}_{h}$ then $l_{i, h}=0$. However, this case is not relevant for the parameters under which EMP emerges (see online Appendix A).
} 


$$
l_{i, h}= \begin{cases}0, & \text { if } w_{h} \leq w_{i, F g} \\ \bar{l}_{h}, & \text { if } w_{h}>w_{i, F g} \text { and } I_{i}\left(\bar{l}_{h}\right) \leq \underline{c} \\ (1-\mu) \bar{l}_{h}-\mu \frac{w_{i, F g}-\underline{c}+\epsilon}{w_{h}-w_{i, F g}}, & \text { if } w_{h}>w_{i, F g} \text { and } I_{i}\left(\bar{l}_{h}\right)>\underline{c}\end{cases}
$$

There is a complication related to determining the cutoff point between the second and the third regime, i.e., the point where $I_{i}=\underline{c}$. Income $I_{i}$ is itself a function of $l_{i, h}$, as given by (3). To resolve this issue, we use the fact that in the second regime $l_{i, h}=\bar{l}_{h}$, so that the corresponding female income is given by $I_{i}\left(\bar{l}_{h}\right)=w_{i, F g}\left(1-\bar{l}_{h}\right)+w_{h} \bar{l}_{h}$. This is the maximum income that can be earned when $w_{h}>w_{i, F g}$, under the constraint $b \geq \underline{b}$. We can thus use the income condition $I_{i}\left(\bar{l}_{h}\right) \leq \underline{c}$ to determine the cutoff point between the second and the third regime.

Note that $I_{i}\left(\bar{l}_{h}\right)$ is increasing in the horn land-labor ratio because all wage rates increase in $t_{h} / l_{h}$ (see equations (12) and (16)). In addition, $w_{h} / w_{i, F g}$ rises with $t_{h} / l_{h}$, as given by (17). The transition from the first to the third regime can thus be illustrated as a function of the land-labor ratio in horn, as shown in Figure $2 .{ }^{30}$ The upper panel depicts both $w_{h} / w_{i, F g}$ and $I_{i}\left(\bar{l}_{h}\right) / \underline{c}$ as functions of $t_{h} / l_{h}$, for women with strength $\rho_{i}=0.5$ (the average in our calibration below). The lower panel shows the corresponding female labor supply in horn, $l_{i, h}$, as well as the birth rate $b_{i}$. Because of the wage premium condition (dashed line), work in horn is viable for female strength-type $i$ only if it pays more than the marginal product in grain production, $w_{i, F g}=\rho_{i} w_{M g}$. Thus, for $w_{h} / w_{i, F g} \leq 1$, women of strength $\rho_{i}$ do not work in horn, such that $l_{i, h}=0$ (regime 1 in (19)). Growing $t_{h} / l_{h}$ eventually leads to $w_{h} / w_{i, F g}>1$, making the horn sector attractive for female labor (beyond point A). The exact level of $l_{i, h}$ then depends on the income condition, depicted by the solid line in the upper panel. When $t_{h} / l_{h}$-and thus income-is low, i.e., if $I_{i}\left(\bar{l}_{h}\right) / \underline{c} \leq 1$, women of type $i$ are still below the reference level $\underline{c}$. In this case, they supply the maximum possible female labor in horn, $l_{i, h}=\bar{l}_{h}$ (regime 2).

Further increases in $t_{h} / l_{h}$ finally allow consumption above the reference level $\underline{c}$ (point $\mathrm{B}$, where $I_{i} / \underline{c}=1$ ). With $t_{h} / l_{h}$ rising beyond this point (regime 3 ), two effects govern female labor supply decisions. First, the wage premium effect leads to more work in horn when $w_{h}$ increases relative to $w_{i, F g}$. Second, the income effect implies less female labor in horn production (and more children) as income grows. ${ }^{31}$ The income effect dominates for all relevant land-labor ratios in our model. ${ }^{32}$ Therefore, $l_{i, h}$ falls in $t_{h} / l_{h}$.

\footnotetext{
${ }^{30}$ At this point, it is convenient to focus on the horn land-labor ratio. All qualitative arguments also hold for the aggregate land-labor ratio $T / N$ (Proposition 1). However, to derive the exact (increasing) functional relationship between $T / N$ and $t_{h} / l_{h}$, we have to solve for the general equilibrium of the model. Here, it is sufficient to concentrate on the partial equilibrium for a given $t_{h} / l_{h}$ in order to illustrate the intuition for female labor supply decisions.

${ }^{31}$ To understand the income effect, suppose that $I_{i}$ is close to, but larger than, $\underline{c}$. Thus, $l_{i, h}$ is below its upper bound. Now suppose that productivity falls at the same rate in both grain and horn, pulling income yet closer to the reference level but leaving $w_{h} / w_{i, F g}$ unchanged. As a result, the marginal utility of consumption rises dramatically. Therefore, for a given premium $w_{h}>w_{i, F g}$, female peasants shift labor supply to the horn sector, delaying marriage and giving birth to fewer children over their lifetime. Consequently, the income effect implies that wage rates and female labor shares in horn move in opposite directions.

32 Technically, the income effect is strong when $I_{i}$ is relatively close to $\underline{c}$, and eventually becomes minuscule for very large land-labor ratios - in the limit, the model behaves like a standard log-utility setup such as in Galor and
} 

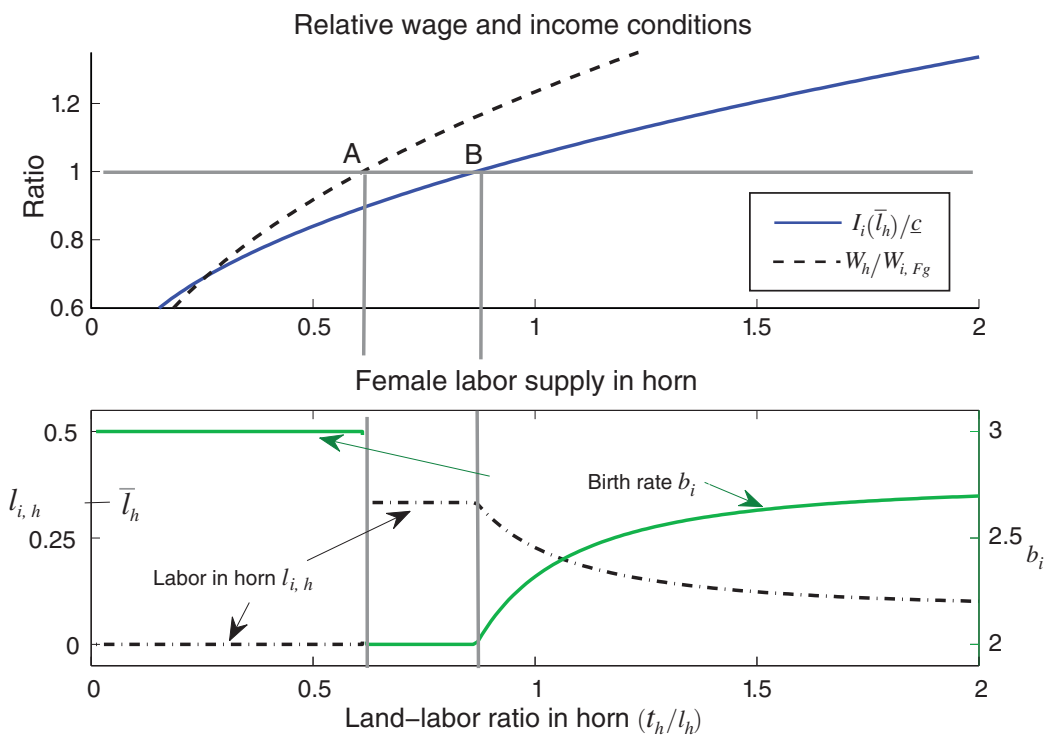

Figure 2. Female Labor in Horn Production for Mean Strength $\rho_{i}$

Notes: For land-labor ratios $t_{h} / l_{h}$ below point A, the horn technology is not feasible for women of strength $\rho_{i}$ because it does not offer a wage premium $\left(w_{h} / w_{i, F} \leq 1\right)$. Thus, female labor in horn is zero. Beyond point $\mathrm{A}$, the horn technology becomes economically viable $\left(w_{h}>w_{i, F}\right)$. Between A and $\mathrm{B}$, female income for strength-type $\rho_{i}$ is below subsistence $\left(I_{i} \leq \underline{c}\right)$, implying large marginal returns to consumption and thus maximum female labor in horn $\left(l_{i, h}=\bar{l}_{h}\right)$. To the right of $\mathrm{B}$, the subsistence effect becomes less important as $t_{h} / l_{h}$ increases further, and $l_{i, h}$ falls. The figure uses the mean strength from our calibration, $\rho_{i}=0.5$. The lower panel also shows the corresponding birth rate $b_{i}$.

This discussion leads to a crucial condition for the emergence of EMP:

PROPOSITION 2: Women of strength $\rho_{i}$ make optimal fertility decisions in line with EMP (Definition 1) over some range of aggregate land-labor ratios $(T / N)$ if and only if $\left.\frac{T}{N}\right|_{w_{h}=w_{i, F}}<\left.\frac{T}{N}\right|_{I_{i}=\underline{c}}$, i.e., if the horn technology offers a wage premium for strength $\rho_{i}$ at land-labor-ratios that do not yet grant the reference consumption for this strength-type.

\section{PROOF:}

See online Appendix A.1, where we show that $b_{i}<\bar{b}$ and that $b_{i}$ is upward sloping in income over some range if the condition holds, while $b_{i}$ is always downward sloping otherwise.

While Proposition 2 is formulated for the more general aggregate land-labor ratio, it equivalently applies to the horn-specific land-labor ratio $t_{h} / l_{h}$ (Proposition 1). Proposition 2 thus implies that point A in Figure 2 has to be to the left of point B for EMP to emerge. In other words, EMP-fertility behavior emerges for a given

Weil (1996). At these high land labor ratios, the wage premium effect is also small relative to the income level. Thus, $l_{i, h}$ and $b_{i}$ approximately become constant in the limit (see online Appendix A.1 for further details). 
strength when income is below $\underline{c}$ at the point where horn becomes economically viable. In this case, the income effect overcompensates the wage premium effect. Thus, on net, $l_{i, h}$ falls in the land-labor ratio-and birth rates rise. On the other hand, if $\mathrm{A}$ lies to the right of $\mathrm{B}$, the income effect is relatively weak: When horn becomes viable, women are already relatively rich. At the same time, the horn wage premium is small relative to income. In this setting, women do not forego children for work in horn, so that $l_{i, h}=0 .{ }^{33}$ Thus, EMP does not emerge. The proof of the proposition builds on this intuition.

Proposition 2 has implications for the relative productivity across sectors that allows EMP to emerge. We assume that the densely populated pre-plague economy has low land-labor ratios such that the horn sector is only attractive for few women. The plague causes massive land abundance. Corollary 2 discusses under which condition this leads to the emergence of fertility behavior in line with EMP.

COROLLARY 2: The following properties favor the emergence of EMP fertility behavior after large population losses: (i) TFP in the grain sector, $A_{g}$, is relatively low; (ii) TFP in the horn sector, $A_{h}$, is relatively high; (iii) on average women are relatively unproductive in grain production (the mean of $\rho_{i}$ is relatively small); and (iv) horn is a luxury product so that its relative price increases with income.

\section{PROOF:}

See online Appendix A.2.

We show in Section II, subsection I that conditions (i)-(iii) were more likely to hold in Europe than in China when both regions were hit by the plague in the fourteenth century. Historical evidence presented in Section IIB also suggests that demand for horn surged after the Black Death, supporting condition (iv).

\section{E. Heterogeneous Strength, Aggregate Labor in Horn, and Fertility}

So far, we have analyzed fertility and labor supply decisions for individual women of a given strength $\rho_{i}$. We now derive the aggregate behavior, averaging across all strength types. The average birth rate is given by $b=\int_{0}^{1} b_{i}\left(\rho_{i}\right) f\left(\rho_{i}\right) d \rho_{i}$. We use a beta distribution for $f(\cdot)$, which ensures that female strength $\rho$ is in the unit interval. We set both shape parameters equal to two-this is the simplest form of a symmetric distribution with mean $0.5 .{ }^{34}$ Figure 3 shows that women of low and high strength react differently to rising land-labor ratios. We use values for $\rho_{i}^{\text {low }}$ and $\rho_{i}^{\text {high }}$ that are one standard deviation below and above the mean of our strength type distribution, respectively. The left panel shows that women with $\rho_{i}^{\text {low }}$ begin to work in horn at relatively low land-labor ratios (point $\mathrm{A}$ ). This is because their foregone wage in grain production is low, so that even small horn wages are attractive. In addition, income in point $\mathrm{A}$ is below the reference level $\underline{c}$. Thus, the horn wage premium provides a

\footnotetext{
33 Technically, the third line in (19) becomes negative if $w_{i, F g}-\underline{c}$ is large relative to $w_{h}-w_{i, F g}$. Thus, the constraint $l_{i, h} \geq 0$ is binding. Intuitively, the wage premium (and thus the cost of children) is so low that-if they could - women would pay to have more than $\pi$ children.

${ }^{34}$ Online Appendix C shows the distribution. Higher values for the shape parameters lead to tighter distributions. We show in online Appendix F that our results are robust to alternative specifications.
} 

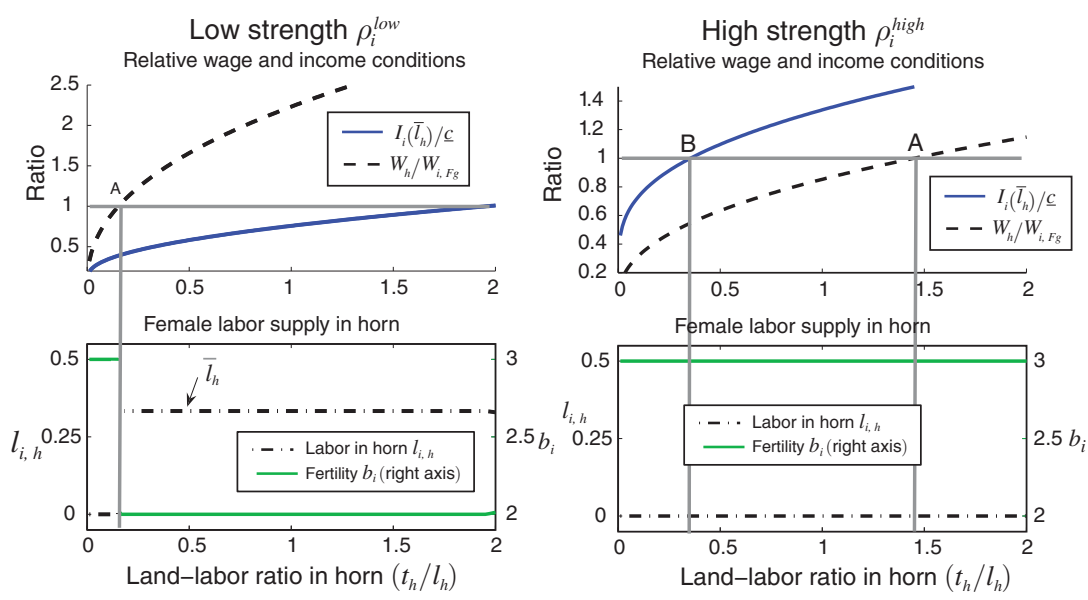

Figure 3. Female Labor Supply in Horn for Low- And High-Strength Types

Notes: See Figure 2 for a description of points A and B. The left (right) panel uses female strength one standard deviation below (above) the mean in our calibration ( $\rho_{i}^{\text {low }}=0.276$ and $\rho_{i}^{\text {high }}=0.724$, respectively).

large marginal utility, so that women of type $\rho_{i}^{\text {low }}$ work the maximum amount of time in horn, $\bar{l}_{h}$. This is in stark contrast to women with strength $\rho_{i}^{\text {high }}$ (right panel). For these, income exceeds $\underline{c}$ already at low land-labor ratios due to their high productivity in grain. At the same time, the horn sector is unattractive, not offering them a wage premium. ${ }^{35}$ Thus, physically strong women do not work in horn, because for them point $\mathrm{A}$ is located to the right of point $\mathrm{B}$ (when horn becomes viable, income already exceeds the reference level $\underline{c}$ ). Note that increasing female strength moves point $\mathrm{A}$ to the right and point $\mathrm{B}$ to the left-making it less likely that fertility restriction will arise for stronger women. In online Appendix $\mathrm{C}$, we discuss this in more detail and derive the cutoff strength type $\rho_{A=B}$ for which A and B coincide-i.e., the maximum female strength at which women still make fertility choices in line with EMP.

Next, we derive the average horn labor supply and fertility across all strength types. Figure 4 shows the average woman's labor in horn, implied by individual behavior together with the strength distribution. Initially, female labor in horn rises in the land-labor ratio. This is because horn becomes attractive for increasingly stronger women. They work at the limit $\bar{l}_{h}$, because their income is below $\underline{c}$ (see the left panel of Figure 3). Eventually, at sufficiently high land-labor ratios, further increases do not attract additional women into horn production. ${ }^{36}$ In addition, women who already work in horn provide less labor than previously because their wages are above the reference level $\underline{c}$ (see the range to the right of point B in Figure 2). In combination, an increase in the land-labor ratio first fosters female labor in horn, but eventually leads to declining labor in horn by raising female incomes beyond $\underline{c}$.

\footnotetext{
${ }^{35}$ For large land-labor ratios, the horn sector will eventually offer a wage premium. However, this is so small relative to income that it does not incentivize women to work in horn (see footnote 33).

${ }^{36}$ At such high land-labor ratios, horn offers a wage premium even for strong types with $\rho_{i}>\rho_{A=B}$. However, for these women work in horn is not attractive (their point A lies to right of point B; see the right panel of Figure 3, as well as online Appendix C).
} 


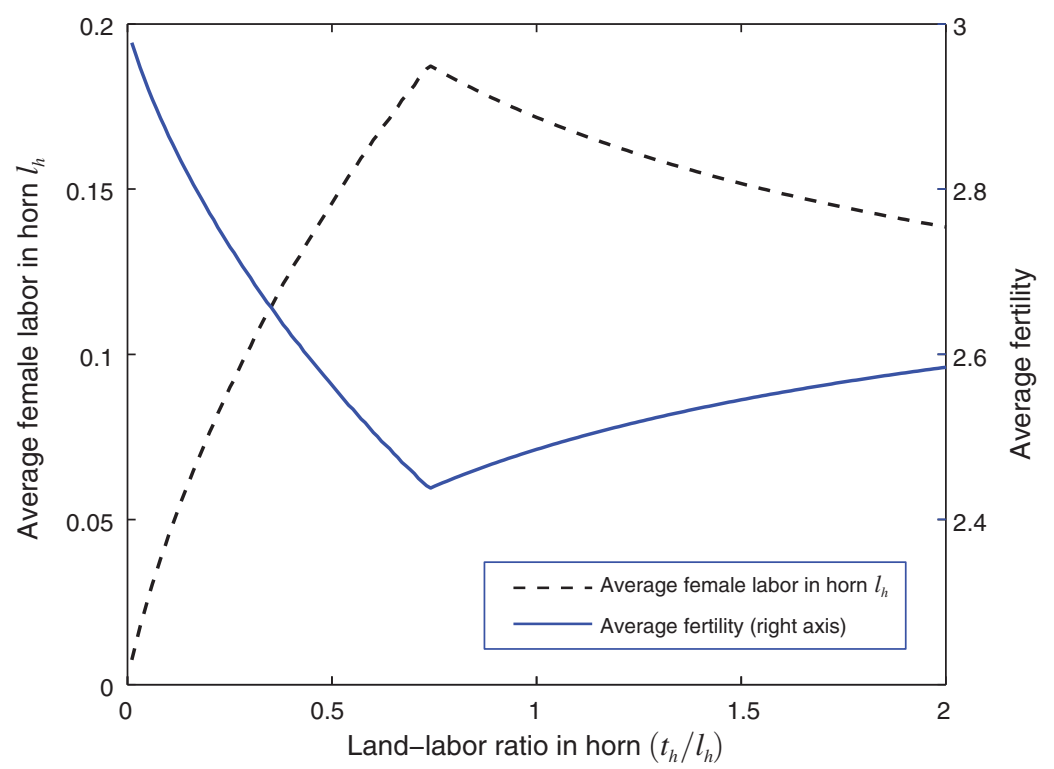

Figure 4. Aggregate Horn Labor Supply and Fertility

Correspondingly, fertility first decreases with land abundance but then increases. Note that throughout this discussion we have focused on the female labor supply in partial equilibrium. In the following, we close the model by adding labor and goods demand. This allows us to determine two central parameters in general equilibrium that we have taken as given so far - the share of land dedicated to horn production $\left(t_{h}\right)$, and the relative price of horn $\left(p_{h}\right)$.

\section{F. Closing the Model: Demand Side and Market Clearing}

In this section we introduce the consumption preferences across the two goods, describe demand, and close the model. We use standard Stone-Geary preferences, where consumption of horn products only takes place if at least $\underline{c}$ of grain is consumed. This is in line with our interpretation of $\underline{c}$ as a reference consumption level that satisfies basic needs. For women with $I_{i}>\underline{c}$, the expenditure shares for the two products are given by

$$
\begin{aligned}
\frac{c_{i, g}}{I_{i}} & =\phi+(1-\phi)\left(\frac{\underline{c}}{I_{i}}\right) \\
\frac{p_{h} c_{i, h}}{I_{i}} & =(1-\phi)-(1-\phi)\left(\frac{\underline{c}}{I_{i}}\right),
\end{aligned}
$$

where $c_{i, g}\left(c_{i, g}\right)$ is grain (horn) consumption of women with strength-type $i$, and $\phi$ is the weight on the grain part of utility. ${ }^{37}$ When $I_{i} \leq \underline{c}$, all income is used for grain consumption: $c_{i, g}=I_{i}$ and $c_{i, h}=0$. Preferences of male peasants have the

\footnotetext{
${ }^{37}$ The ratio of expenditures for the two products can be written as $\left(c_{i, g}-\underline{c}\right) /\left(p_{h} c_{i, h}\right)=\phi /(1-\phi)$. Thus, the expenditure shares relative to $\underline{c}$ are constant, as in a common Cobb-Douglas utility setup.
} 
same structure, with $I_{i}$ replaced by $w_{M g}$. Online Appendix D states the preferences in detail and shows that the implied indirect utility is compatible with our general setup in (2). The expenditure shares in (20) imply that once consumption passes the reference level, peasants spend growing proportions of their income on horn products. For very high income levels $I_{i}>>\underline{c}$, the horn expenditure share converges to the constant $1-\phi$. Therefore, the horn demand effect driven by the non-homothetic preferences is strongest when income is still relatively low, which coincides with the emergence of EMP.

Aggregate demand for the two products is obtained by integrating over all strength types for the $N$ women, and by using the homogeneous income $w_{M G}$ for the $N$ men. Market clearing implies that total peasant expenditures for each product must equal total output, net of the landlord's consumption. We have now fully specified the model; we first solve it for a given land-labor ratio $t=T / N$. This yields aggregate birth rates and death rates as functions of $t$-and thus also as functions of income per capita. In online Appendix E we show the related algebra and explain how we solve the system of equations.

\section{G. Model Parameters}

Our model's main purpose is to illustrate the mechanism leading to the emergence of EMP. We estimate the quantitative importance of our mechanism in the empirical section below. Thus, the exact parameter values mainly serve an illustrative purpose. Whenever concrete numbers for parameters can be derived from historical figures, we use these. For the remainder, we choose simple approximations. We focus on England, where data is relatively abundant, and where births were particularly responsive to economic conditions (Lee 1981; Wrigley and Schofield 1981). For the labor shares of production in grain and horn we use $\alpha_{g}=0.7$ and $\alpha_{h}=0.4 .^{38}$ For the average productivity of women relative to men in grain we use $\rho=0.5$, reflecting the fact that English women's wages were equivalent to 50-63 percent of English male wages (Kussmaul 1981; Allen 2009); this is also compatible with the range reported by van Zanden (2011) for relative female wages in reaping and haymaking. For the corresponding beta distribution we use a simple symmetric form with a mean of 0.5 (as discussed in Section IIE). ${ }^{39}$

Turning to the demographic parameters, we choose $\pi=3$ (peasant families have three children when women do not work in horn), $\underline{b}=2$ (two children is the lower bound for birth rates). This captures the fact that EMP avoided up to one-third of all births (Clark 2007) ${ }^{40}$ For the elasticity of death rates with respect to income we

\footnotetext{
${ }^{38}$ This is calculated as follows: We take the estimates of revenue and cost on arable and pastoral farms from Allen (1988) and combine them with the figures for labor cost per acre from Allen (1991). We find that both relative to costs and revenue, labor's share in pastoral farming is approximately half of the value in arable production. This determines the relative magnitudes of $\alpha_{g}$ and $\alpha_{h}$. To calculate the levels, we use an average labor share in agriculture of 0.5 . According to the figures in Broadberry, Campbell, and van Leeuwen (2011), arable production was 32 percent of total agricultural production, while pastoral farming accounted for 68 percent. We chose $\alpha_{g}=0.7$ and $\alpha_{h}=0.4$ so that the average weight of labor in agriculture is identical with the value of 0.5 : $0.32 \times 0.7+0.68 \times 0.4=0.496$.

${ }^{39}$ Our baseline setup with both parameters of the distribution equal to 2 implies a standard deviation of 0.22 . The model is robust to alternative parameters. For example, choosing 5 instead of 2 for both parameters (implying a standard deviation of 0.15 ) yields very similar results.

${ }^{40}$ Note that this is a conservative choice for an upper bound. Because strong women do not work in horn, aggregate fertility does not drop down to $\underline{b}$. Choosing lower values for $\underline{b}$ implies a steeper decline in fertility.
} 


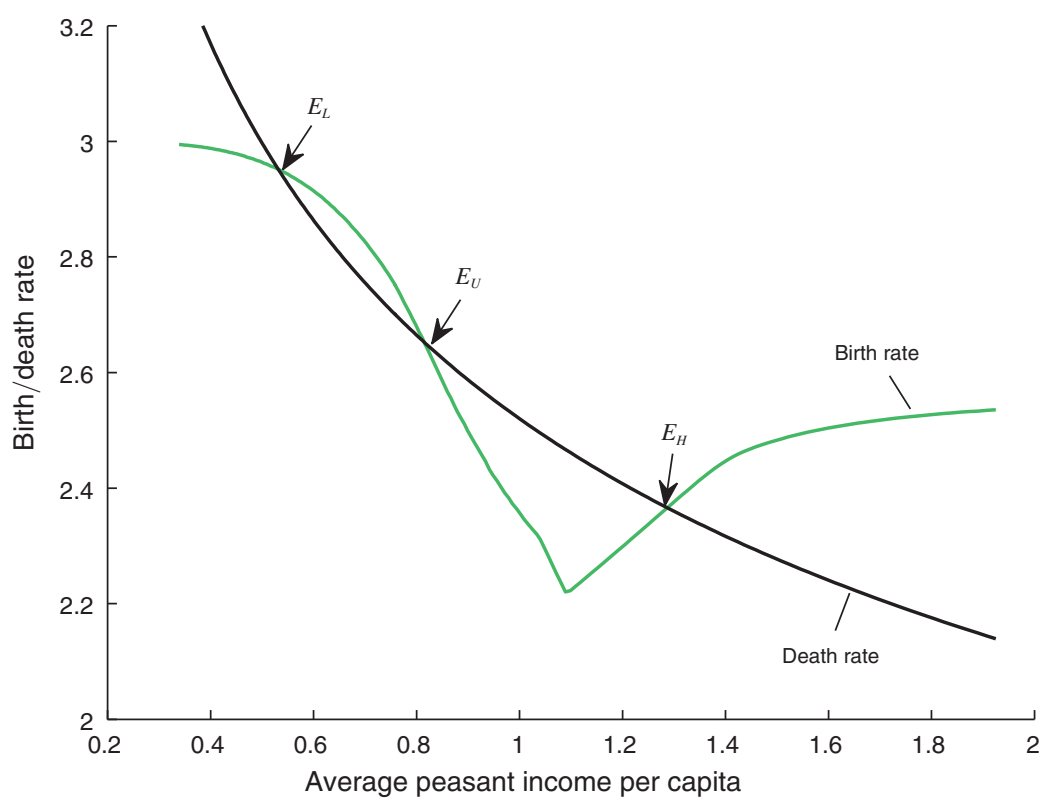

Figure 5. Steady States

use $\varphi_{d}=-0.25$. This is the average across all 50-year estimates for England from Kelly and Ó Grada (2010) between 1600 and $1800 .{ }^{41}$ We choose $d_{0}=0.84 \pi$ in (6). This implies that there is already some horn production prior to the Black Death. Dyer (1988) shows that livestock products account for about 50 percent of the value of food consumption during the high-wage decades after 1350. The corresponding share in the model is given by $1-\phi$ for a rich economy. We thus use $\phi=0.5$ for the parameter in the Stone-Geary utility function. The remaining parameters can be chosen with greater degrees of freedom. We use $\mu=0.5$ for the relative importance of children in female utility (alternatively, 0.25 or 0.75 yield very similar results). We normalize $\underline{c}=1$ and land $T=1$. Finally, we choose TFP in grain and horn, $A_{g}=3.5$ and $A_{h}=1.50$.

\section{H. Steady States and Stability of EMP}

We now turn to the steady states and the contribution of EMP to sustaining higher per capita income levels after the Black Death. Figure 5 shows the simulation results for our complete model. We plot average peasant household income on the vertical axis, which increases in the land-labor ratio. The economy has two stable steady states. The first $\left(E_{L}\right)$ has high population pressure and low per capita income, while the second $\left(E_{H}\right)$ involves lower fertility and higher peasant income. The unstable steady state $E_{U}$ lies in between. A large income shock (such as the Black Death) can trigger the emergence of EMP. This occurs when the increase in land-labor ratios is large enough to push the economy beyond $E_{U}$, inducing the transition from $E_{L}$ to

\footnotetext{
${ }^{41}$ In online Appendix F we discuss the implications of alternative choices for this parameter.
} 
$E_{H}$. Average peasant income at $E_{H}$ is about double the pre-plague level. While this is above the increase in wages after the Black Death, we do not expect our simple parameterization to pin down historical magnitudes exactly. ${ }^{42}$ What is important is that our findings underline the role of fertility restriction for increasing living standards in early modern Europe. At the same time, it is clear that EMP alone cannot account for all of the European (English) lead in terms of per capita income in 1700. Additional factors may include a different mortality regime, as well as (to a limited extent) technological change. We examine the contributions of these two other factors in Voigtländer and Voth (2013) in detail.

\section{International Comparisons}

Europe was not the only area to suffer from deadly plagues. Yet it is the only one to have evolved a regime of fertility restriction based on a socioeconomic institution that avoided births through delayed marriage. In this section, we argue that specific European characteristics are responsible for the emergence of EMP, and that other regions were less likely to evolve a similar way of reducing fertility.

Divergence within Europe.-Fertility control in Northwestern Europe was particularly stringent. In Southern Europe, EMP reduced fertility by less. In Eastern Europe, EMP did not exist at all. Why did such differences evolve?

In Southern Europe, both age at first marriage and the percentage never marrying were lower than in the Northwest. Population recovered relatively quickly from the impact of the Black Death. In Italy and Spain, it returned to the pre-1350 peak by the sixteenth century. In contrast, England probably did not reach pre-plague population levels until the seventeenth or even the eighteenth century. ${ }^{43}$ Rapid recoveries of Southern European populations also reversed post-plague wage gains. Changes in agriculture were less pronounced there. In particular, while the temporary spike in incomes after 1350 improved wages, it did not lead to the evolution of service as a standard phase in the transition from childhood to adulthood. If the shock of the plague was similar, why did it not cause similar social and economic changes? According to Corollary 2, $A_{h} / A_{g}$ is crucial. We argue that low horn productivity $A_{h}$ prevented the emergence of EMP in Southern Europe, while high grain productivity $A_{g}$ had the same effect in Eastern Europe.

Agricultural conditions in Mediterranean countries did not favor the pastoral farming of the type common in Northwestern Europe. In particular, low rainfall made it impossible to keep large herds of cattle and sheep in the same area yearround. Transhumance - the driving of livestock from one area to another-is an ancient custom in Mediterranean countries, with numerous routes recorded as far back as Roman times. The most famous is arguably the Spanish Mesta- a council of shepherds that controlled transhumance under a grant from the Spanish King, allowing them to drive their flocks across a vast stretch of territory extending from

\footnotetext{
${ }^{42}$ We obtain similar results for perfect substitutability between horn and grain, i.e., when shutting down the demand effect so that all results are driven by land abundance (online Appendix F).

${ }^{43}$ There is considerable uncertainty about the size of the pre-plague population in England. Slow recovery was not a universal feature of the Northwestern European experience-the Netherlands experienced rapid population growth (Pamuk 2007).
} 
Extremadura and Andalusia to Castile. ${ }^{44}$ Traversing sparsely populated areas on their own was not compatible with women's social role in early modern Europe. Work in husbandry was predominantly performed by men. Without the rise of service in husbandry as a typical phase in young women's life, marriage ages remained low. ${ }^{45}$

In Eastern Europe, grain productivity was high. Especially in Western Russia and Ukraine, land is unusually fertile (Nunn and Qian 2011). In addition, labor was not free, and wages did not surge to the same extent as in Western Europe after the plague. Instead, landlords continued to farm their estates using serf labor in arable production. Population declines in Eastern Europe were probably smaller than they were in the West (Benedictow 2004). In the presence of high grain productivity, and without a major jump in land-labor ratios, cattle and sheep farming remained uncompetitive vis-à-vis grain production.

Comparison with China.-China also suffered from a devastating plague outbreak in the fourteenth century, but it did not develop fertility restriction comparable to EMP. We first summarize Chinese demographic patterns and then apply the main insights from our model to this case. Why did the same shock not lead to the emergence of a "low pressure" demographic regime? We argue that high Chinese grain productivity $A_{g}$ was key.

In contrast to Europe, marriage in China occurred early and was near-universal for women. For the period 1640-1870, the percentage of women not married by age 30 ranged from 4 percent in Beijing to 1 percent in Liaoning (Lee and Feng 1999). The age at first marriage for women was also low. Amongst members of the Imperial Qing family in Beijing, age at first marriage was 15.5-19 years in the seventeenth century. By 1840, it had risen to 22 years. Marriage outside the urban areas, and amongst those not belonging to the nobility, probably continued to occur much earlier. In the early twentieth century, Chinese women on average married by age 17.5 (Lee, Feng, and Ruan 2001). ${ }^{46}$

In online Appendix $\mathrm{C}$ we show that grain production in China was approximately four times more efficient than in England. Following Corollary 2, higher grain productivity makes the emergence of EMP less likely, by lowering the wage premium that horn labor can offer to women. Thus, our model suggests that-paradoxicallyChina's high land productivity, as emphasized by the revisionist "California School" (Pomeranz 2000; Goldstone 2003), undermined the evolution of fertility limitation. Also, as population pressure mounted in China, ploughing with oxen disappeared. Consequently, the strength requirements for grain and rice production were lower. This eroded the relative male advantage in the grain (rice) sector. Therefore, the

\footnotetext{
${ }^{44}$ Originally, shepherds took advantage of the agricultural no-man's-land between Christian and Muslim areas of control. Gradually, the use became institutionalized.

${ }^{45}$ Similar questions could be raised about the non-emergence of EMP in the early medieval period, when landlabor ratios were high. For the emergence of EMP, a large-scale, commercial-operated horn sector is key. While we do not explicitly model this aspect, functioning markets for relatively long-distance trade were crucial. These did not exist in the early Middle Ages.

${ }^{46}$ While irrelevant for fertility, the same was not true in the case of men. A significant proportion remained unmarried by age 30 . The main reason was the unavailability of women. Due to female infanticide, and the practice of taking multiple wives, many men could not marry. The overall proportion in 1800 was around 22 percent, compared to 45 percent in England, Norway, and Sweden. The average age at marriage for men was 21-22 (Lee and Feng 1999). Online Appendix C provides further discussion.
} 
relative female productivity in grain, $\rho$, was higher than in Europe. As Corollary 2 shows, this made the emergence of EMP more difficult. In sum, large $A_{g}$ paired with relatively high $\rho$ in China avoided the shift to pastoral agriculture and thus the emergence of a female labor market outside the household.

\section{Empirical Evidence}

According to our model, pastoral production leads to more employment opportunities for women as servants. This causes the female age at first marriage to rise. In this section, we test this prediction. We first show that pastoral production was indeed correlated with a high share of unmarried females, and that this was already true in the Middle Ages. To demonstrate this, we use several types of new data. From fourteenth century tax records, we construct proxies for the share of unmarried females, county-by-county, in 1381 - shortly after the plague. In addition, we use detailed data from employment records of early modern English farms to show that pastoral farms used female labor on a far greater scale.

The second prediction of our model concerns the expansion of pastoral production after 1349. We show that there was a massive rise in pastoral output as incomes surged. We then examine our third empirical prediction - that late female marriage was "sticky." Once EMP had reached its full strength, it did not disappear for centuries. We analyze data on the female age at first marriage in panel of parishes, compiled by the Cambridge Group of Population Studies (CAMPOP). High suitability for pastoral agriculture (due to soil and climate characteristics) predicts markedly later ages at first marriage for women. In addition, in these areas, servants mostly worked in livestock farming, as indicated by the seasonality of marriages. Finally, where a drastic shift away from arable farming toward pastoral farming occurred after the Black Death, female ages at marriage were markedly higher even centuries later. Table 2 summarizes the evidence we employ and the steps of the causal chain they refer to. In the following, we begin with evidence from the Middle Ages, move on to the early modern period, and then use data from the mid-nineteenth century.

\section{A. Pastoral Production and Unmarried Females in the Middle Ages}

Since there is no direct way to estimate the age at first marriage in England before the sixteenth century, we rely on a proxy variable for marriage behavior- the implied share of unmarried women as reflected in the poll tax returns of 1377 and 1381. ${ }^{47}$ The tax charge levied on each person increased three-fold over the four years. This lead to wide-spread evasion in 1381, with the number of tax payers dropping by more than one-third: "[E]very shire of England returned an incredibly small number of adult inhabitants liable to the impost. The adult population of the realm had ostensibly fallen from 1,355,201 to 896,481 persons. These figures were monstrous and incredible (Oman 1906)." What is of interest to us is which taxpayers disappeared from the records between 1377 and 1381: "A glance at the details of the township-returns ... reveals the simple form of evasion ... most villages show an

\footnotetext{
${ }^{47}$ If women eventually get married, the proportion of unmarried females is a good proxy for the age at first marriage.
} 
TABle 2-Steps of Mechanism and Empirical Variables

\begin{tabular}{|c|c|c|c|c|}
\hline Pastoral production & $\Rightarrow$ & Farm service & $\Rightarrow$ & Late/no marriage \\
\hline $\begin{array}{l}\text { - Percent of land used for } \\
\text { pasture in } 1290,1837 \\
\text { - Deserted medieval villages } \\
\text { - Soil and climate suitability: } \\
\text { days of grass growth (IV) }\end{array}$ & & $\begin{array}{l}\text { - Seasonality of marriage pattern } \\
1561-1820 \\
\text { - Employment share of servants } \\
\text { in } 1851 \text { census }\end{array}$ & & $\begin{array}{l}\text { - Percent drop in number of } \\
\text { taxpayers } 1377 / 1381 \\
\text { - CAMPOP data on female age } \\
\text { at first marriage } \\
\text { - Percent of unmarried women in } \\
1851 \text { census }\end{array}$ \\
\hline
\end{tabular}

Notes: The table summarizes the steps of our casual argument and the evidence we employ. We argue that (i) pastoral production was typically associated with (ii) farm service (husbandry), which forced female servants to (iii) postpone marriage or remain celibate.

enormous and impossible predominance of males in their population, and an equally incredible want of unmarried females." ${ }^{48}$ In online Appendix F we provide confirming evidence from a sample of 193 settlements in 22 counties for which individual poll tax records survived. We show that "missing unmarried women" can account for a substantial proportion of the drop in tax payers.

There is data on the aggregate number of taxpayers in 1377 and 1381 for 38 counties. The drop in their number has a mean of 0.33 and ranges from 0.07 to 0.65 . We use data on land usage in 1290 (Pastoral ${ }^{1290}$ ) from (2011) to determine which counties were predominantly pastoral. ${ }^{49}$ Figure 6 shows a strong and positive correlation of the drop in taxpayers with the share of pastoral land in 1290. In Table 3, we test the link statistically. Column 1 shows that the correlation is positive and highly significant. In column 2, we control for population density, and column 3 includes regional fixed effects. The size and significance of the coefficient on pastoral land use is largely unaffected. The magnitude of the coefficient indicates that a onestandard deviation (0.15) increase in the share of pastoral land in 1290 is associated with a $10-15$ percent drop in the number of tax payers. ${ }^{50}$

One obvious concern is omitted variable bias, with a variety of factors influencing marriage ages or celibacy that could be correlated with pastoral land use. ${ }^{51}$ To sidestep causality issues, we exploit the suitability of land and climatic conditions for grazing as an instrument, using the number of days during which grass can grow in different English counties from Down et al. (1981). ${ }^{52}$ The exclusion restriction

\footnotetext{
${ }^{48}$ Oman (1906, p. 23); our emphasis. For full quotation, see online Appendix I. A similar point is made by Goldberg (1990, p. 195): "Married couples are seemingly over-numerous; solitaries, females especially, but also servants, too few. The population recorded compares unfavourably ... with totals recorded for earlier taxes." Without massive evasion, the overall turnout of the poll taxes in 1377 and 1381 should have been similar-in the former, every person of 14 years and older was liable, in the latter, everybody 15 and over.

${ }^{49}$ Broadberry, Campbell, and van Leeuwen (2011) give information on the share of land used for arable farming. We use (1-arable) as our measure of pastoral farming. In online Appendix E we show that this proxy is very close to the actual share of pastoral land (using data from 1836), and that it is strongly associated with livestock production.

${ }^{50}$ In online Appendix F, we examine the proportion of unmarried men in a sample of settlement-level tax returns - this proxy allows us to shed more light on the magnitude of effects. We show that a one standard deviation increase in Pastoral $^{1290}$ is associated with roughly a 3.7 percent decline in the proportion of unmarried men.

${ }^{51}$ Such a factor could be higher per capita income driving up the demand for dairy and beef, and simultaneously encouraging later marriage.

${ }^{52}$ Online Appendix E provides additional details and shows that the first-stage relationship between the share of pastoral land and $\ln$ (daysgrass) is strong and robust to controlling for general crop suitability. It also shows that our results are very similar when including general crop suitability as an additional instrument, predicting which regions are relatively less suitable for pastoral production because of their high arable productivity.
} 


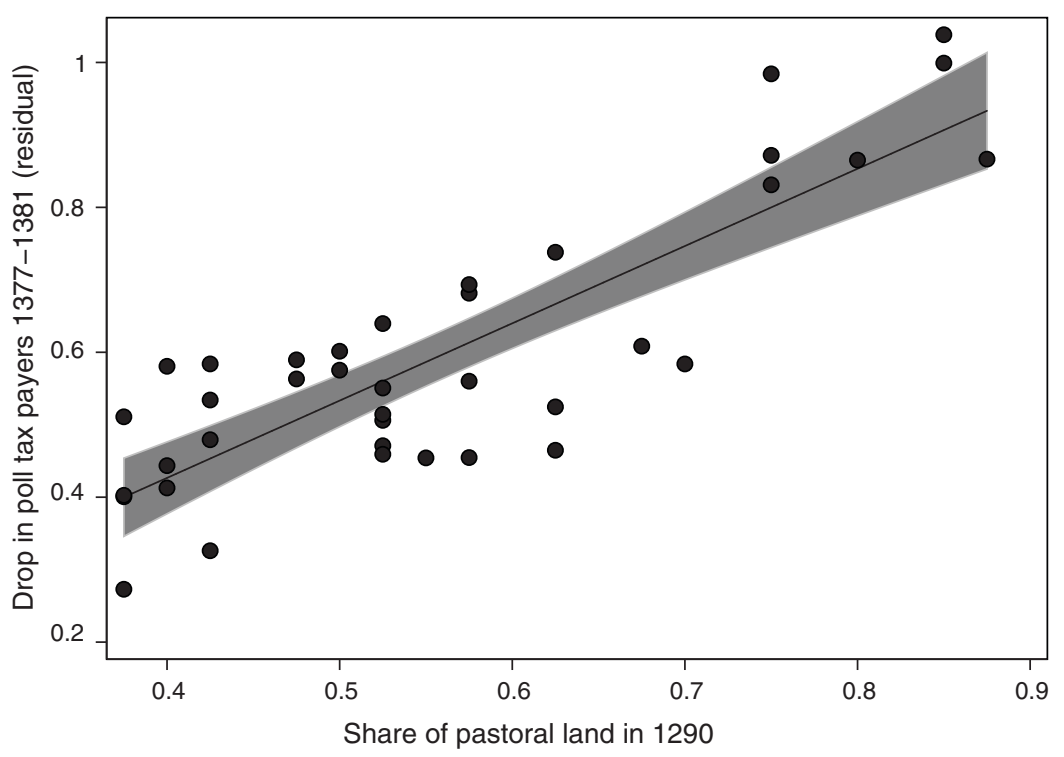

Figure 6. Celibacy and Pastoral Production: Evidence from the 1381 Poll Tax (Partial Scatterplot)

Notes: The $y$-axis plots the residual variation in the percentage drop in tax payers between 1377-1381, after controlling for county-level population density in 1290. County-level poll tax data for 1377 and 1381 are from Fenwick (1998, 2001, 2005).

is that female marriage age is only influenced by grass suitability via the effect on the share of pastoral land in each county. ${ }^{53}$ In column 4 we use $\ln$ (daysgrass) as an instrument for Pastoral ${ }^{1290}$. The instrument is strong, with the first-stage $F$-statistic well above 10. The estimated coefficient under IV is larger than in the same specification under OLS (column 1). This is what one should expect given that the pastoral share in 1290 is only a proxy and likely measured with error.

\section{B. Agricultural Production and Consumption after the Black Death}

Prior to the Black Death, population was increasing while land was in fixed supply-output per capita was stagnant (Campbell 2000; Broadberry, Campbell, and van Leeuwen 2011). Then, the Black Death killed one-third to half of the population. Output per capita surged, and 1350 became a turning point for real wages. By 1450, real wages in England were 50 percent higher than they had been on the eve of the plague (Clark 2005). Per capita consumption of food overall increased. As consumers grew richer, their consumption patterns shifted from "corn to horn" (Campbell 2000). More money was spent on "luxury foods:" Meat and milk consumption increased markedly. For farm workers on large estates, we can quantify these changes: the percentage of calories from meat and fish rose from 7 percent

\footnotetext{
${ }^{53}$ Note that we instrument for the proportion of land used in pastoral production, so that the extent to which our instrument is correlated with overall agricultural fertility does not affect our results.
} 
Table 3-Pastoral Production and a Proxy for the Proportion of Unmarried Women, 1381

\begin{tabular}{|c|c|c|c|c|}
\hline Drop in tax payers, $1377-1381$ & $\begin{array}{c}\text { OLS } \\
(1)\end{array}$ & $\begin{array}{c}\text { OLS } \\
(2)\end{array}$ & $\begin{array}{c}\text { OLS } \\
(3)\end{array}$ & $\begin{array}{l}\text { IV } \\
(4)\end{array}$ \\
\hline Pastoral $^{1290}$ & $\begin{array}{l}0.682^{* * * *} \\
(0.116)\end{array}$ & $\begin{array}{l}1.067 \text { *** } \\
(0.304)\end{array}$ & $\begin{array}{l}0.804 * * * \\
(0.275)\end{array}$ & $\begin{array}{l}0.952 * * * \\
(0.180)\end{array}$ \\
\hline $\ln ($ popdensity $)$ & & $\begin{array}{c}0.133 \\
(0.107)\end{array}$ & $\begin{array}{c}0.125 \\
(0.115)\end{array}$ & \\
\hline Region FE & No & No & Yes & No \\
\hline$R^{2}$ & 0.483 & 0.515 & 0.649 & \\
\hline Observations & 38 & 38 & 38 & 38 \\
\hline Instrument & & & & $\ln$ (daysgrass) \\
\hline First stage $F$-statistic ${ }^{\mathrm{a}}$ & & & & 43.4 \\
\hline
\end{tabular}

Notes: We use the drop in the number of tax payers between 1377 and 1381 as a proxy for the proportion of unmarried women at the county level. The regressions thus indicate that more pastoral counties had more unmarried women. Robust standard errors in parenthesis. Pastoral ${ }^{1290}$ is calculated as 1 minus the proportion of land used for arable production in 1290, and popdensity is the population per square mile at the county level in 1290; both variables are from Broadberry, Campbell, and van Leeuwen (2011).

${ }^{\text {a }}$ Kleibergen-Paap rK Wald $F$-statistic. The corresponding Stock-Yogo value for 10 percent maximal IV bias is 16.4 .

*** Significant at the 1 percent level.

** Significant at the 5 percent level.

* Significant at the 10 percent level.

in 1256 to 26 percent in 1424 (Dyer 1988). The Great Plague also caused major changes in production (Apostolides et al. 2008):

Between the mid-thirteenth century and the mid-fourteenth century, factor costs and property rights encouraged lords to ... concentrate on arable production. Following the Black Death, however, lords found it ... increasingly expensive to hire wage labour, following a substantial increase in wage rates. ... Lords ... switched away from labour intensive arable production to mixed husbandry and pastoral production, leaving arable production to peasants who could rely mainly on family labour...

Campbell (2000) estimates that grain acreage declined by approximately 15 percent after 1349, while livestock reared for meat and milk increased by up to 90 percent. Sheep-farming husbandry expanded everywhere. The estimates of Broadberry, Campbell, and van Leeuwen (2011) suggest that pastoral output increased rapidly between 1348 and 1555, while arable output only grew slowly. The share of pastoral production in agricultural value added went from 47 to 70 percent, while that of arable declined from 53 to 30 percent between 1270-1279 and 1450-1459.

Large landowners switched to pastoral farming for two reasons: First, it economized on labor. Per acre, husbandry required 15-25 percent fewer hands than arable production (Allen 1988). Second, cheap labor (in particular, of women) replaced that of adult males. We use data from Allen's (1988) estimates of labor usage to demonstrate the size of the effects involved. The average reduction in labor cost is substantial-for farms of the same size, the labor cost per acre on average was fully a quarter lower. Since pastoral farms were on average five times larger, they also profited from economies of scale (Allen 1988). In combination, this means that 
average costs per acre in pasture were 75 percent lower than in arable farming. ${ }^{54}$ Allen's (1991) early modern data also demonstrate that switching from arable to pastoral farming was associated with a larger role for women in the labor force. Switching to livestock farming increased the share of females employed from 26 to 34 percent on smaller farms (100 acres), and from 19 to 31 percent on larger ones (250 acres; see online Appendix A for details). This is because livestock production is particularly well-suited to women and children (Smith 1981). Work as shepherdesses, as milkmaids, or in spinning required less physical strength than plough agriculture. The switch from "corn to horn" therefore implied a shift in demand from male to female labor. It also involved hiring more help from outside the family. Allen (1988) shows that the average ratio of hired to family labor was 2.3:1 in pastoral farming, but only $1.5: 1$ in arable. ${ }^{55}$

\section{Pastoralism and Marriage Ages after 1600}

Next, we examine the association between pastoral output and marriage ages during the early modern period. We first show that the share of land used for livestock farming is a good predictor of the age at first marriage, and that the shift out of arable and into pastoral farming after the Black Death is also associated with a higher age at first marriage. In addition, we demonstrate that spring marriage-reflecting the seasonality of pastoral agriculture-is a strong predictor of late female marriage. Finally, the 1851 British census provides direct evidence that farm service was associated with markedly lower marriage rates.

As the main dependent variable, we use detailed data from family reconstitutions compiled by CAMPOP, which reconstructed the complete family "trees" of 26 parishes in England starting in 1541 (Wrigley et al. 1997). ${ }^{56}$ The average age of first marriage for women in the sample is 25.0 , with a (county-level) minimum of 21.6 and a maximum of 28.6 .

How much of the variation in marriage ages can be explained by the prevalence of pastoral farming and the switch from "corn to horn" in the Middle Ages? One direct measure of the switch to pastoral production comes from deserted medieval villages (DMVs) in England (Beresford 1989). Villages were abandoned in the late medieval period for a variety of reasons, including general population decline after the Black Death. One important consequence was the move to pastoral farming, especially sheep farming - areas where once cereals had been cultivated by local farmers were turned over to grazing. ${ }^{57}$

The shift to pastoral farming was massive, and it was near-permanent. If we simply examine mean first female marriage age, conditional on the density of DMVs

\footnotetext{
${ }^{54}$ Online Appendix A provides more detail on these numbers and plots the cost of labor per acre for a variety of farm sizes, for both pastoral and arable farms. Allen's data is based on Arthur Young's travels in England during the eighteenth century. He argues that labor-saving in pastoral farming relative to arable was even stronger in 1600 and 1700 (Allen 1988).

${ }^{55}$ In online Appendix B, we examine anthropological evidence on the use of female labor. It clearly shows that pastoral agriculture is more compatible with the employment of women.

56 Their data on age at marriage is given for 26 parishes and five periods between 1600 and 1837 . We georeferenced the parishes analyzed by CAMPOP and matched them to county-level data on agricultural production and suitability.

${ }^{57}$ Broadberry, Campbell, and van Leeuwen (2011) exploit information on DMVs to quantify the change from "corn to horn" after 1290. A full quote of their assessment is in online Appendix I.
} 
Table 4-Pastoral Production and Age at First Marriage (Parish-Level Panel)

\begin{tabular}{|c|c|c|c|c|c|c|}
\hline \multirow{2}{*}{$\begin{array}{l}\text { Period } \\
\text { Female age at first marriage }\end{array}$} & \multicolumn{3}{|c|}{$1600-1837$} & \multicolumn{3}{|c|}{$1600-1749$} \\
\hline & $\begin{array}{l}\text { OLS } \\
(1)\end{array}$ & $\begin{array}{l}\text { OLS } \\
(2)\end{array}$ & $\begin{array}{l}\text { IV } \\
(3)\end{array}$ & $\begin{array}{l}\text { OLS } \\
(4)\end{array}$ & $\begin{array}{c}\text { OLS } \\
(5)\end{array}$ & $\begin{array}{l}\text { IV } \\
(6)\end{array}$ \\
\hline Pastoral $^{1290}$ & $\begin{array}{c}4.036^{*} \\
(2.166)\end{array}$ & $\begin{array}{l}5.973 * * \\
(2.554)\end{array}$ & $\begin{array}{l}8.085^{* * * *} \\
(1.895)\end{array}$ & $\begin{array}{c}4.321 * \\
(2.235)\end{array}$ & $\begin{array}{l}6.817 * * \\
(3.089)\end{array}$ & $\begin{array}{l}\text { 7.759*** } \\
(1.838)\end{array}$ \\
\hline$D M V$ & $\begin{array}{c}5.905^{*} \\
(3.162)\end{array}$ & $\begin{array}{l}7.457 * * \\
(2.879)\end{array}$ & $\begin{array}{l}9.266^{* * * *} \\
(2.938)\end{array}$ & $\begin{array}{c}6.623^{*} \\
(3.614)\end{array}$ & $\begin{array}{c}6.734 \\
(4.470)\end{array}$ & $\begin{array}{l}9.076 \text { *** } \\
(2.916)\end{array}$ \\
\hline Period FE & Yes & Yes & Yes & Yes & Yes & Yes \\
\hline Region FE & No & Yes & No & No & Yes & No \\
\hline$R^{2}$ & 0.448 & 0.669 & - & 0.197 & 0.492 & - \\
\hline Observations & 112 & 112 & 112 & 66 & 66 & 66 \\
\hline Instrument & & & $\ln ($ daysgrass $)$ & & & $\ln ($ daysgrass $)$ \\
\hline First stage $F$-statistic ${ }^{a}$ & & & 30.1 & & & 36.6 \\
\hline
\end{tabular}

Notes: $D M V$ proxies for the shift toward pastoral production after the Black Death. The regressions thus show that female age at first marriage was higher in counties that were (i) already more pastoral before the Black Death in 1349, and (ii) shifted more towards pastoral production thereafter. The panel comprises 26 parishes (located in 15 counties) over 5 periods. All explanatory variable and the instrument are measured at the county level, while the dependent variable is observed at the parish level. Robust standard errors in parentheses (clustered at the county level). Pastoral ${ }^{1290}$ is calculated as 1 minus the proportion of land used for arable production in 1290, and daysgrass denotes the days per year during which grass grows at the county level (see online Appendix E for details). DMV denotes the number of deserted medieval villages per 100,000 acres at the county level.

${ }^{a}$ Kleibergen-Paap rK Wald $F$-statistic (cluster-robust). The corresponding Stock-Yogo value for 10 percent maximal IV bias is 16.4 in both columns 3 and 6 .

*** Significant at the 1 percent level.

** Significant at the 5 percent level.

* Significant at the 10 percent level.

per county, we find a clear pattern. Online Appendix G provides a more detailed analysis and shows the distributional graph. The modal age at marriage was markedly higher in parts of England with more abandoned medieval villages, reflecting a strong shift toward pastoralism after the Black Death.

In Table 4, we examine the effect of pastoralism and DMVs on the female age at first marriage. In columns 1-3, we present results for the entire period covered by CAMPOP - five periods between 1600 and $1837 .{ }^{58}$ We find strong effects throughout. Both Pastoral ${ }^{1290}$ and DMV are significantly correlated with the female age at first marriage in our panel (column 1). Using fixed effects for larger regions to control for unobserved heterogeneity (column 2) does not change our results. In column 3 we re-estimate our results with $\ln$ (daysgrass) as an instrument for Pastoral ${ }^{1290}$. We find large and significant coefficients for both the share of pastoral land use in 1290 as well as for our proxy of medieval land conversion to livestock farming $(D M V)$. The coefficients are similar if we restrict our sample to the period 1600-1749 excluding the period after the onset of the Industrial Revolution (columns 4-6). The effects are quantitatively important. A one standard deviation increase in the share of land devoted to pastoral farming in 1290 (0.15) went hand-in-hand with average female first marriages occurring 0.6-1.2 years later; a one standard deviation

\footnotetext{
${ }^{58}$ All regressions include period fixed effects. The 26 parishes are located in 15 different counties. Because the explanatory variables are observed for each county, we cluster standard errors at the county level.
} 
increase in the number of DMVs per 100,000 acres raised marriage ages by a third to half a year. How important was pastoral production overall for late marriage? The variable Pastoral ${ }^{1290}$ has a mean of 0.57 . Given our preferred specifications in Table 4-the IV estimates in columns 3 and 6-this implies that pastoralism overall raised the average age of female marriage by more than four years.

We can also show that the link between pastoral land use and late female marriage is closely associated with the employment of female servants in the pastoral sector. Kussmaul (1990) collected data on the seasonality of marriage from Anglican marriage registers for 542 parishes in England. These are classified as pastoral-type $(\mathrm{P})$ if marriage frequency during the autumn was low, but high in the spring: Servants in husbandry would typically marry after the lambing season in spring. Workers in arable areas, in contrast, often married after the harvest season, in the late summer. We use the county-level share of parishes with spring marriage pattern as the explanatory variable. ${ }^{59}$ Table 5 shows a strong positive association between pastoral marriage patterns and the age at first marriage. In column 1, we exploit both timeseries and cross-sectional variation. The effect is strong and significant in the sample overall (panel A), but it is smaller and not statistically significant when we exclude data after 1749 (panel B). Column 2 includes time period dummies to control for overall trends in pastoral production and age at marriage. While the magnitude of the coefficients is unchanged, the standard errors are now marginally greater than necessary for conventional levels of significance.

The Kussmaul measure is inherently noisy because many other factors besides work in husbandry affect the date of marriage. To deal with measurement error, we instrument spring marriages by land use and soil suitability. IV-results (columns 3 and 4) indicate large and significant effects. For example, the estimation results in column 3-where we instrument with the pastoral share in 1290-suggest that a one standard deviation increase in the share of parishes with a pastoral marriage pattern (0.13) would raise mean female age at first marriage by 0.8 years. When using the number of days of grass growth as an instrument, the effect is 30 percent larger. This implies that the part of marriage seasonality driven by pastoral land use is a powerful predictor of late marriage. The part of the variation in pastoral marriages explained by actual land use or land suitability arguably captures the husbandry channel best. This strongly suggests that pastoral agriculture reduced fertility by offering extra employment possibilities to female servants. In online Appendix $\mathrm{H}$ we exploit the detailed data available in the 1851 British census to provide further evidence for the main mechanism. While agriculture was a declining part of the English economy, areas that employed farm servants still saw markedly later marriage ages.

In sum, the historical data strongly support all the steps in the causal chain in Table 2. Where women had more employment opportunities in pastoral farming, and more females worked as servants, marriage occurred later. The part of pastoral land use driven by climatic conditions is particularly strongly associated with higher marriage ages; where medieval farms switched from "corn to horn," as reflected by

\footnotetext{
${ }^{59}$ Kussmaul (1990) provides data for three periods between 1561 and 1820 . We match these to the five CAMPOP periods. Online Appendix G provides a more detailed description, as well as scatterplots for the regressions presented in the main text.
} 
Table 5-Pastoral Marriage Pattern and Age at First Marriage

\begin{tabular}{|c|c|c|c|c|}
\hline Female age at first marriage & $\begin{array}{l}\text { OLS } \\
(1)\end{array}$ & $\begin{array}{l}\text { OLS } \\
(2)\end{array}$ & $\begin{array}{l}\text { IV } \\
\text { (3) }\end{array}$ & $\begin{array}{l}\text { IV } \\
(4)\end{array}$ \\
\hline \multicolumn{5}{|c|}{ Panel A. Parish level panel, 1600-1837 } \\
\hline PastoralMarriage & $\begin{array}{l}4.436^{* * *} \\
(2.054)\end{array}$ & $\begin{array}{c}3.288 \\
(2.421)\end{array}$ & $\begin{array}{l}6.149 * * \\
(2.656)\end{array}$ & $\begin{array}{l}9.488 \text { *** } \\
(0.991)\end{array}$ \\
\hline Period dummies & No & Yes & Yes & Yes \\
\hline$R^{2}$ & 0.096 & 0.410 & - & - \\
\hline Observations & 112 & 112 & 112 & 112 \\
\hline Instrument & & & Pastoral $^{1290}$ & $\ln$ (daysgrass) \\
\hline First stage $F$-statistic ${ }^{\mathrm{a}}$ & & & 7.5 & 53.2 \\
\hline \multicolumn{5}{|c|}{ Panel B. Parish level panel for $1600-1749$} \\
\hline PastoralMarriage & $\begin{array}{c}2.681 \\
(2.353)\end{array}$ & $\begin{array}{c}2.612 \\
(2.445)\end{array}$ & $\begin{array}{l}6.611 * * * \\
(2.121)\end{array}$ & $\begin{array}{l}9.566 \text { *** } \\
(0.731)\end{array}$ \\
\hline Period dummies & No & Yes & Yes & Yes \\
\hline$R^{2}$ & 0.058 & 0.060 & - & - \\
\hline Observations & 66 & 66 & 66 & 66 \\
\hline Instrument & & & Pastoral $^{1290}$ & $\ln ($ daysgrass $)$ \\
\hline First stage $F$-statistic ${ }^{\mathrm{a}}$ & & & 11.0 & 25.2 \\
\hline
\end{tabular}

Notes: The regressions show that the female age at first marriage was higher in parishes where marriages typically occurred in spring (after the lambing season), i.e., in parishes with a pastoral marriage pattern. The panel comprises 26 parishes (located in 15 counties) over 5 periods. PastoralMarriage is the share of parishes with pastoral (spring) marriage pattern in a county (classified as "P" by Kussmaul 1990). Pastoral ${ }^{1290}$ is calculated as 1 minus the proportion of land used for arable production in 1290, and daysgrass denotes the days per year during which grass grows at the county level (see online Appendix E for details). All explanatory variables and instruments are measured at the county level, while the dependent variable is observed at the parish level. Robust standard errors in parentheses (clustered at the county level). All regressions are weighted by the number of parishes in each county for which the pastoral marriage pattern is reported in Kussmaul (1990).

${ }^{a}$ Kleibergen-Paap rK Wald $F$-statistic (cluster-robust). The corresponding Stock-Yogo value for 10 percent maximal IV bias is 16.4 in both columns 3 and 4 in both panels.

*** Significant at the 1 percent level.

** Significant at the 5 percent level.

* Significant at the 10 percent level.

the share of deserted medieval villages, early modern English women took their vows markedly later.

\section{Conclusion}

Why did Europe evolve a system of delayed marriage that reduced fertility centuries before the demographic transition? We argue that the Black Death was one crucial contributing factor. Fertility restriction emerged as an indirect consequence of the abundance of land after 1348-1350, and the associated switch from arable to pastoral farming. The Black Death reduced population by between one-third and half. Land-labor ratios rose markedly. This favored pastoral production because it uses land more intensively (Campbell 2000). Cattle were kept for meat and milk, and sheep for mutton and wool. The rise of large-scale livestock farming translated into a greater economic role for women. Female labor is better suited to shepherding and milking than to ploughing or threshing (Alesina, Giuliano, and Nunn 2011) — a 
fact borne out by the sexual division of labor in isolated tribes studied by anthropologists (online Appendix B). After the plague, owners of large estates switched from arable farming, with its high demand for adult male labor, to husbandry, which required less strenuous labor, some of which could be supplied by women. In this way, the Black Death raised the demand for female labor.

Working as a servant involved moving from the parental household to the master's. Contracts forbade marriage. Because the Black Death changed the pattern of production and raised the demand for female labor, it increased the average age at first marriage for women, reducing fertility rates. This in turn lowered population pressure in a Malthusian setting and helped to keep wages high after the Black Death. We thus explain the simultaneous emergence of large-scale pastoral farming, late marriage, higher incomes, and low fertility.

We test the predictions of our model against data from England between the fourteenth and nineteenth century. Using information from the Cambridge Group of Population Studies' family reconstitutions, we show that counties specializing in pastoral production registered markedly later average ages at first marriage. In the late fourteenth century already, areas with more livestock farming had a higher proportion of unmarried women. Also, where farming switched from "corn to horn" after 1350 — as evidenced by numerous medieval villages becoming deserted after the plague-marriage occurred much later, even centuries after the Black Death. These effects are arguably causal. Using a pastoral suitability index based on rainfall and soil temperature as an instrument, we find large and highly significant effects of livestock farming on marriage ages. Overall, we estimate that the existence of a pastoral sector in the English economy raised marriage ages by more than 4 yearsequivalent to roughly half of the increase between the Middle Ages and the early modern period.

European women already married later than the age of biological fertility as early as the late Roman period. However, fertility restriction via this channel only became severe in the early modern period, when ages at first marriage in many areas reached levels only seen again today. In a Malthusian world, this had implications for per capita incomes. When birth (or death) rates change, the "iron law of wages" need not hold. ${ }^{60}$ Lower fertility in Europe as a result of EMP was one important factor for the persistence of unusually high per capita incomes long before the Industrial Revolution. In models in the spirit of Acemoglu and Zilibotti (1997) and Voigtländer and Voth (2006), higher incomes facilitate the transition to self-sustaining growth. By stabilizing incomes at a high level by 1700, EMP may well have laid some of the foundations for Europe's industrialization. EMP also reduced the volatility of income-bad shocks were partly compensated by lower fertility. Paradoxically, one of the weaknesses of the European agricultural system-relatively low land productivity in grain — strengthened fertility restriction after the Black Death, laying one of the foundations for Europe's early rise to riches.

\footnotetext{
${ }^{60}$ Mokyr and Voth (2010) distinguish between a weak and a strong form of the Malthusian model, where the former is subject to the same equilibrating forces, and the latter implies the "iron law of wages."
} 


\section{REFERENCES}

Acemoglu, Daron, Simon Johnson, and James Robinson. 2005. "The Rise of Europe: Atlantic Trade, Institutional Change, and Economic Growth.” American Economic Review 95 (3): 546-79.

Acemoglu, Daron, and Fabrizio Zilibotti. 1997. "Was Prometheus Unbound by Chance? Risk, Diversification, and Growth." Journal of Political Economy 105 (4): 709-51.

Alesina, Alberto F., Paola Giuliano, and Nathan Nunn. 2011. "On the Origins of Gender Roles: Women and the Plough." National Bureau of Economic Research Working Paper 17098.

Allen, Robert C. 1988. "The Growth of Labor Productivity in Early Modern English Agriculture." Explorations in Economic History 25 (2): 117-46.

Allen, Robert C. 1991. "The Two English Agricultural Revolutions: 1450-1850.” In Land, Labour and Livestock: Historical Studies in European Agricultural Productivity, edited by Bruce Campbell and Mark Overton, 236-54. Manchester: Manchester University Press.

Allen, Robert C. 2009. "Agricultural Productivity and Rural Incomes in England and the Yangtze Delta, c. 1620-c. 1820.” Economic History Review 62 (3): 525-50.

Apostolides, Alexander, Stephen Broadberry, Bruce Campbell, Mark Overton, and Bas van Leeuwen. 2008. "English Agricultural Output and Labour Productivity, 1250-1850: Some Preliminary Estimates." http://www.basvanleeuwen.net/bestanden/agriclongrun1250to1850.pdf.

Ashraf, Quamrul, and Oded Galor. 2011. "Dynamics and Stagnation in the Malthusian Epoch." American Economic Review 101 (5): 2003-41.

Barro, Robert J., and Gary S. Becker. 1989. "Fertility Choice in a Model of Economic Growth." Econometrica 57 (2): 481-501.

Becker, Gary S. 1960. "An Economic Analysis of Fertility." In Demographic and Economic Change in Developed Countries, 209-31. Princeton, NJ: Princeton University Press.

Becker, Gary S., and H. Gregg Lewis. 1973. "On the Interaction between the Quantity and Quality of Children." Journal of Political Economy 81 (2): 279-88.

Becker, Gary S. 1981. A Treatise on the Family. Cambridge, MA: Harvard University Press.

Benedictow, Ole J. 2004. The Black Death, 1346-1353: The Complete History. Woodbridge: Boydell Press.

Beresford, Maurice. 1989. "A Review of Historical Research (to 1968)." In Deserted Medieval Villages, edited by Maurice Beresford and J. G. Hurst, 3-75. Gloucester: Alan Sutton Publishing.

Boldrin, Michele, and Larry E. Jones. 2002. "Mortality, Fertility, and Saving in a Malthusian Economy." Review of Economic Dynamics 5 (4): 775-814.

Broadberry, Stephen, Bruce M. S. Campbell, and Bas van Leeuwen. 2011. "Arable Acreage in England, 1270-1871." Unpublished.

Brown, John C., and Timothy W. Guinnane. 2001. "The Fertility Transition in Bavaria.” Yale University Economic Growth Center Discussion Paper 821.

Butz, William P., and Michael P. Ward. 1979. "The Emergence of Countercyclical US Fertility." American Economic Review 69 (3): 318-28.

Campbell, Bruce M. S. 2000. English Seigniorial Agriculture, 1250-1450. New York: Cambridge University Press.

Chenery, Hollis, Moises Syrquin, and Hazel Elkington. 1975. Patterns of Development, 1950-1970. New York: Oxford University Press.

Chesnais, Jean-Claude. 1992. The Demographic Transition: Stages, Patterns and Economic Implications. New York: Cambridge University Press.

Clark, Gregory. 2005. "The Condition of the Working Class in England, 1209-2004." Journal of Political Economy 113 (6): 1307-40.

Clark, Gregory. 2007. A Farewell to Alms: A Brief Economic History of the World. Princeton, NJ: Princeton University Press.

Coale, Ansley J., and Susan Cotts Watkins, eds. 1986. The Decline of Fertility in Europe. Princeton, NJ: Princeton University Press.

Crafts, Nicholas, and Terence C. Mills. 2009. "From Malthus to Solow: How Did the Malthusian Economy Really Evolve?" Journal of Macroeconomics 31 (1): 68-93.

De Moor, Tine, and Jan Luiten van Zanden. 2010. "Girl Power: The European Marriage Pattern and Labour Markets in the North Sea Region in the Late Medieval and Early Modern Period." Economic History Review 63 (1): 1-33.

Devolder, Daniel. 1999. Hajnal's European Marriage Pattern and the Evolution of Agrarian Structures. Fort Worth, TX: Social Science History Association.

Doepke, Matthias. 2004. "Accounting for Fertility Decline during the Transition to Growth." Journal of Economic Growth 9 (3): 347-83. 
Doepke, Matthias, Moshe Hazan, and Yishay Maoz. 2012. “The Baby Boom and World War II: A Macroeconomic Analysis." Unpublished.

Doepke, Matthias, and Fabrizio Zilibotti. 2008. "Occupational Choice and the Spirit of Capitalism." Quarterly Journal of Economics 123 (2): 747-93.

Down, K., J. Jollans, A. Lazenby, and R. Wilikins. 1981. "The Distribution of Grassland and Grassland Usage in the UK." In Grassland in the British Economy, edited by J. L. Jollans, 580-83. Reading, UK: University of Reading Centre for Agricultural Study.

Dyer, Christopher. 1988. "Changes in Diet in the Late Middle Ages: The Case of Harvest Workers." Agricultural History Review 36 (1): 21-37.

Epstein, S. R. 2000. Freedom and Growth: The Rise of States and Markets in Europe, 1300-1750. London: Routledge.

Fenwick, C., ed. 1998. The Poll Taxes of 1377, 1379, and 1381: Bedfordshire-Leicestershire. Oxford University Press for British Academy Records of Social and Economic History.

Fenwick, C., ed. 2001. The Poll Taxes of 1377, 1379, and 1381: Lincolnshire-Westmorland. Oxford University Press for British Academy Records of Social and Economic History.

Fenwick, C., ed. 2005. The Poll Taxes of 1377, 1379, and 1381: Wiltshire-Yorkshire. Oxford University Press for British Academy Records of Social and Economic History.

Fernández-Villaverde, Jesús. 2001. "Was Malthus Right? Economic Growth and Population Dynamics.” Penn Institute for Economic Research Working Paper 01-046.

Flinn, Michael Walter. 1981. The European Demographic System, 1500-1820. Baltimore: Johns Hopkins University Press.

Foreman-Peck, James. 2009. "The Western European Marriage Pattern and Economic Development." Cardiff Economics Working Paper 2009/15.

Galloway, Patrick R. 1988. "Basic Patterns in Annual Variations in Fertility, Nuptiality, Mortality, and Prices in Pre-industrial Europe." Population Studies 42 (2): 275-302.

Galor, Oded. 2005. "From Stagnation to Growth: Unified Growth Theory." In Handbook of Economic Growth, Volume 1A, edited by Philippe Aghion and Stephen N. Durlauf, 171-293. New York: Elsevier.

Galor, Oded, and Omer Moav. 2002. "Natural Selection and the Origin of Economic Growth." Quarterly Journal of Economics 117 (4): 1133-91.

Galor, Oded, and David N. Weil. 1996. "The Gender Gap, Fertility, and Growth.” American Economic Review 86 (3): 374-87.

Galor, Oded, and David N. Weil. 1999. "From Malthusian Stagnation to Modern Growth." American Economic Review 89 (2): 150-54.

Galor, Oded, and David N. Weil. 2000. "Population, Technology, and Growth: From Malthusian Stagnation to the Demographic Transition and Beyond." American Economic Review 90 (4): 806-28.

Goldberg, P. J. P. 1990. "Urban Identity and the Poll Taxes of 1377, 1379, and 1381." Economic History Review, Second Series 43 (2): 194-216.

Goldstone, Jack. 2003. "Feeding the People, Starving the State: China's Agricultural Revolution of the Seventeenth and Eighteenth Centuries." Global Economic History Network Conference, London.

Greenwood, Jeremy, Ananth Seshadri, and Guillaume Vandenbroucke. 2005. "The Baby Boom and Baby Bust." American Economic Review 95 (1): 183-207.

Hajnal, John. 1965. "European Marriage Patterns in Perspective." In Population in History, edited by David V. Glass and David E. C. Eversley. London: Edward Arnold.

Hajnal, John. 1982. "Two Kinds of Preindustrial Household Formation System." Population and Development Review 8 (3): 449-94.

Hallam, H. E. 1985. "Age at First Marriage and Age at Death in the Lincolnshire Fenland, 1252-1478." Population Studies 39 (1): 55-69.

Hansen, Gary D., and Edward C. Prescott. 2002. "Malthus to Solow." American Economic Review 92 (4): 1205-17.

Heckman, James J., and James R. Walker. 1990. “The Third Birth in Sweden.” Journal of Population Economics 3 (4): 235-75.

Herlihy, David. 1985. Medieval Households. Cambridge, MA: Harvard University Press.

Herlihy, David. 1997. The Black Death and the Transformation of the West. Cambridge, MA: Harvard University Press.

Hume, David. 1854. "Of the Populousness of Ancient Nations.” In Philosophical Works, Essay XI. London: Black and Tait.

Ingram, Martin. 1985. "The Reform of Popular Culture? Sex and Marriage in Early Modern England." In Popular Culture in Seventeenth-Century England, edited by Barry Reay, 129-165. Beckenham: Croom Helm. 
Jones, Charles I. 2001. "Was an Industrial Revolution Inevitable? Economic Growth over the Very Long Run." Advances in Macroeconomics 1 (2): 1-45.

Kelly, Morgan, and Cormac Ó Grada. 2008. "The Poor Law versus the Positive Check: Living Standards and Mortality in England since the Middle Ages." Unpublished.

Kelly, Morgan, and Cormac Ó Grada. 2010. "Living Standards and Mortality since the Middle Ages." Unpublished.

Kremer, Michael. 1993. "Population Growth and Technological Change: One Million B.C. to 1990." Quarterly Journal of Economics 108 (3): 681-716.

Kussmaul, Ann. 1981. Servants in Husbandry in Early Modern England. New York: Cambridge University Press.

Kussmaul, Ann. 1990. A General View of the Rural Economy of England, 1538-1840. New York: Cambridge University Press.

Laslett, Peter, and Richard Wall, eds. 1972. Household and Family in Past Time. New York: Cambridge University Press.

Lee, Ronald. 1981. "Short-Term Variations: Vital Rates, Prices and Weather." In The Population History of England 1541-1871, edited by E. A. Wrigley and R. S. Schofield, 356-401. New York: Cambridge University Press.

Lee, Ronald, and Michael Anderson. 2002. "Malthus in State Space: Macro Economic-Demographic Relations in English History, 1540-1870." Journal of Population Economics 15 (2): 195-220.

Lee, James, and Wang Feng. 1999. "Malthusian Models and Chinese Realities: The Chinese Demographic System 1700-2000.” Population and Development Review 25 (1): 33-65.

Lee, James, Wang Feng, and Danching Ruan. 2001. "Nuptiality among the Qing Nobility, 16401900." In Asian Population History, edited by Ts'ui-jung Liu et al., 353-73. Oxford: Clarendon University Press.

Lucas, Robert E. 2002. “The Industrial Revolution: Past and Future.” In Lectures on Economic Growth. Cambridge, MA: Harvard University Press.

Macfarlane, Alan. 1970. The Family Life of Ralph Josselin: A Seventeenth-Century Clergyman. New York: Norton.

Maddison, Angus. 1995. Monitoring the World Economy: 1820-1992. Paris: Organisation for Economic Co-operation and Development.

Malthus, Thomas Robert. 1798. An Essay on the Principle of Population. London: J. Johnson.

Mincer, Jacob. 1963. "Market Prices, Opportunity Costs and Income Effects." In Measurement in Economics, edited by Carl Christ, 67-82. Stanford: Stanford University Press.

Mitterauer, M. 2003. Warum Europa? Mittelalterliche Grundlagen eines Sonderwegs. Munich: C. H. Beck.

Mokyr, Joel. 1990. The Lever of Riches: Technological Creativity and Economic Progress. Oxford: Oxford University Press.

Mokyr, Joel, and Hans-Joachim Voth. 2010. "Understanding Growth in Europe, 1700-1870: Theory and Evidence." In The Cambridge Economic History of Modern Europe, Volume 1: 1700-1870, edited by Stephen Broadberry and Kevin O'Rourke, 7-42. Cambridge: Cambridge University Press.

Neher, Philip A. 1971. "Peasants, Procreation, and Pensions." American Economic Review 61 (3): $380-89$.

Nunn, Nathan, and Nancy Qian. 2011. "The Potato's Contribution to Population and Urbanization: Evidence from a Historical Experiment." Quarterly Journal of Economics 126 (2): 593-650.

Oman, Charles. 1906. The Great Revolt of 1381. Oxford: Clarendon Press.

Pamuk, Sevket. 2007. "The Black Death and the Origins of the 'Great Divergence' across Europe, 1300-1600." European Review of Economic History 11 (3): 289-317.

Pomeranz, Kenneth. 2000. The Great Divergence: China, Europe, and the Making of the Modern World Economy. Princeton, NJ: Princeton University Press.

Royal Society of Arts. 1765. Museum Rusticum et Commerciale: Select papers on agriculture, commerce, arts, and manufactures. Great Britain: Printed for R. Davis.

Schellekens, Jona. 1997. "Nuptiality during the First Industrial Revolution in England: Explanations." Journal of Interdisciplinary History 27 (4): 637-54.

Schellekens, Jona. 2001. "Economic Change and Infant Mortality in England, 1580-1837." Journal of Interdisciplinary History 32 (1): 1-13.

Schultz, T. Paul. 1985. "Changing World Prices, Women's Wages, and the Fertility Transition: Sweden, 1860-1910.” Journal of Political Economy 93 (6): 1126-54.

Smith, Richard M. 1981. "Fertility, Economy, and Household Formation in England over Three Centuries." Population and Development Review 7 (4): 595-622.

Snell, Keith D. M. 1981. "Agricultural Seasonal Unemployment, the Standard of Living, and Women's Work in the South and East, 1690-1860." Economic History Review, Second Series 34 (3): 407-37. 
United Kingdom: Office for National Statistics (UK-ONS). 2011. http://www.statistics.gov.uk.

Voigtländer, Nico, and Hans-Joachim Voth. 2006. "Why England? Demographic Factors, Structural Change and Physical Capital Accumulation during the Industrial Revolution.” Journal of Economic Growth 11 (4): 319-61.

Voigtländer, Nico, and Hans-Joachim Voth. 2013. "How the West 'Invented' Fertility Restriction: Dataset." American Economic Review. http://dx.doi.org.10.1257/aer.103.6.2227.

Voigtländer, Nico, and Hans-Joachim Voth. 2013. "The Three Horsemen of Riches: Plague, War, and Urbanization in Early Modern Europe." Review of Economic Studies 80 (2): 774-811.

Vollrath, Dietrich. 2011. "The Agricultural Basis of Comparative Development." Journal of Economic Growth 16 (4): 343-70.

Wrigley, E. A. 1988. Continuity, Chance, and Change: The Character of the Industrial Revolution in England. Cambridge: Cambridge University Press.

Wrigley, E. A., R. S. Davies, J. E. Oeppen, and R. S. Schofield. 1997. English Population History from Family Reconstitution, 1580-1837. Cambridge: Cambridge University Press.

Wrigley, E. A., and R. S. Schofield, eds. 1981. The Population History of England 1541-1871. New York: Cambridge University Press.

van Zanden, Jan Luiten. 2002. "The 'Revolt of the Early Modernists' and the 'First Modern Economy’: An Assessment.” Economic History Review 55 (4): 619-41.

van Zanden, Jan Luiten. 2011. "The Malthusian Intermezzo: Women's Wages and Human Capital Formation between the Late Middle Ages and the Demographic Transition of the Nineteenth Century." Center for Global Economic History Working Paper 14. 